\title{
Review \\ Characteristics and Clinical Application of Extracellular Vesicle-Derived DNA
}

\author{
Jae Young Hur ${ }^{1,2}$ (D) and Kye Young Lee ${ }^{1,3, * \mathbb{D}}$ \\ 1 Precision Medicine Lung Cancer Center, Konkuk University Medical Center, Seoul 05030, Korea; \\ 20160475@kuh.ac.kr \\ 2 Department of Pathology, Konkuk University Medical Center, Seoul 05030, Korea \\ 3 Department of Pulmonary Medicine, Konkuk University School of Medicine, Seoul 05030, Korea \\ * Correspondence: kyleemd@kuh.ac.kr; Tel.: 82-2-2030-7784
}

check for updates

Citation: Hur, J.Y.; Lee, K.Y.

Characteristics and Clinical Application of Extracellular Vesicle-Derived DNA. Cancers 2021, 13, 3827. https://doi.org/10.3390/ cancers13153827

Academic Editors: Klaus Holzmann and Lingeng $\mathrm{Lu}$

Received: 29 June 2021

Accepted: 27 July 2021

Published: 29 July 2021

Publisher's Note: MDPI stays neutral with regard to jurisdictional claims in published maps and institutional affiliations.

Copyright: (c) 2021 by the authors. Licensee MDPI, Basel, Switzerland. This article is an open access article distributed under the terms and conditions of the Creative Commons Attribution (CC BY) license (https:// creativecommons.org/licenses/by/ $4.0 /)$.
Simple Summary: We reviewed characterization and the role of DNAs derived from extracellular vesicles focusing on its use for identifying biomarkers. Extracellular vesicles contain double-stranded genomic DNA reflecting the mutational status and methylation profile of the parental tumor cells. Many studies demonstrated higher stability, sensitivity, and specificity of extracellular vesicle DNAs in comparison to cell-free DNAs, demonstrating a high potential for clinical application as a source for liquid biopsy. Moreover, the horizontally transfer ability of extracellular vesicle DNAs could be utilized in therapeutics.

Abstract: Extracellular vesicles (EVs) carry RNA, proteins, lipids, and diverse biomolecules for intercellular communication. Recent studies have reported that EVs contain double-stranded DNA (dsDNA) and oncogenic mutant DNA. The advantage of EV-derived DNA (EV DNA) over cell-free DNA (cfDNA) is the stability achieved through the encapsulation in the lipid bilayer of EVs, which protects EV DNA from degradation by external factors. The existence of DNA and its stability make EVs a useful source of biomarkers. However, fundamental research on EV DNA remains limited, and many aspects of EV DNA are poorly understood. This review examines the known characteristics of EV DNA, biogenesis of DNA-containing EVs, methylation, and next-generation sequencing (NGS) analysis using EV DNA for biomarker detection. On the basis of this knowledge, this review explores how EV DNA can be incorporated into diagnosis and prognosis in clinical settings, as well as gene transfer of EV DNA and its therapeutic potential.

Keywords: extracellular vesicle; exosome; microvesicle; EV DNA; liquid biopsy; next-generation sequencing; methylation; gene transfer

\section{Introduction}

In light of recent developments in targeted therapies [1], immunotherapies [2], and precision medicine [3], the importance of liquid biopsy for detecting cancer DNA and biomarkers has become obvious [4]. Liquid biopsy can utilize all fluids produced by humans, such as blood [5], urine [6], saliva [7], cerebrospinal fluid [8], ascites [9], and pleural effusion [10]. Currently, blood biopsy is the most frequently utilized diagnostic method for almost all cancers [11]; however, sensitivity can be increased by using specific liquid samples that are related to specific cancers [12], for example, the urine for bladder cancer [13], saliva for head and neck cancer [14], and bronchoalveolar lavage fluid (BALF) for lung cancers [15]. For liquid biopsy, the cell-free nucleic acids (cfNA), circulating tumor cells (CTCs), and extracellular vesicles (EVs) that exist in these specimens are isolated using high-tech equipment, and the isolated materials are further analyzed using next-generation sequencing (NGS), real-time PCR, digital PCR, and/or bioinformatics (BI) for the screening and early detection of cancer $[16,17]$. Furthermore, the information can be helpful in 
deciding a targeted therapy as a companion diagnostic and in the monitoring of treatment response, drug resistance, recurrence, and metastasis [18-21].

EVs, a diverse population of biological particles with sizes ranging from approximately 30 to $1000 \mathrm{~nm}$, emerged into the spotlight as an important source for liquid biopsy [22-25]. The characteristics of EVs include the representation of their original host through their cargo, showing their potential as biomarkers $[15,26]$, and through the transfer of cellular components between cells $[27,28]$. Depending on their origin, biogenesis, and size, EVs are categorized into exosomes, microvesicles, microparticles, and apoptotic bodies [29,30]. However, the term EV is more commonly used in a broader sense, as isolating one specific subcategory remains technically difficult [31].

Early studies have found that EVs are more abundantly shed by cancer cells than normal cells [32]. The same pattern was observed in the plasma of ovarian cancer [33] and non-small-cell lung cancer (NSCLC) patients [34]. EVs carry RNA, DNA, proteins, lipids, and diverse bioactive materials [29]. Initially, studies were predominantly focused on EV RNAs; however, recently, EV-derived DNA (EV DNA) has garnered attention. EV DNAs largely consist of large genomic DNA (gDNA) and tumor-specific oncogenic mutant DNA, unlike fragmented cell-free DNA (cfDNA) $[15,35,36]$. Plasma cfDNA has been the go-to biomarker for diagnosis and prognosis by liquid biopsy because of its easy obtainability; however, the low sensitivity of this approach, because of the short half-life of plasma cfDNA, poses a challenge in its application $[37,38]$. In contrast, the structural stability of EVs renders EV DNA a more ideal subject than free-floating cfDNA, as the lipid bilayer of EVs protects EV DNA from degradation by external factors [39]. Recent publications in NGS studies have demonstrated that EV DNA can serve as a good cancer biomarker $[40,41]$. This review summarizes the current state of understanding of the traits of EV DNA, the DNA loading mechanism, and the application of EV DNA to NGS.

\section{History of Extracellular Vesicles}

Before the first publication that identified and used the term microvesicles in 1975 by Dalton AJ [42], the existence of EVs and their functions were recognized early in several studies, including studies on thromboplastic protein [43], platelet dust [44], and globules [45]. The description and properties of EVs were determined primarily using ultracentrifugation, electron microscopy (EM), and functional studies. Chargaff E. and West R. [43], in 1946, showed that high-speed centrifugation at 31,000 $\mathrm{g}$ for $150 \mathrm{~min}$ significantly extended the clotting time of the supernatant. Wolf $P$ [44] visualized small vesicles originating from platelets and termed them "platelet dust" using electron microscopy, while Bonucci E [45] observed the calcifying property of EVs in the bone matrix.

By the 1980s, the shedding of EVs by tumor cells [46] and EV formation during reticulocyte maturation were recognized, and these vesicles were named exosomes [47,48], advancing the understanding of EV release. Researchers began identifying the contents and functions of EVs, beginning with the study by Ceccarini Met al. [49] in the late 1980s, which identified RNA-containing EVs, and a study in the 1990s that demonstrated immune cells secreting antigen-presenting EVs, which implied a transfer of information between cells [50].

In the 2000s, studies reported that EVs containing RNAs such as mRNA and microRNA have the ability to be transferred from cell to cell [51,52]. The identification of DNA associated with EVs and their possible functions began relatively early, with reports on EV and DNA binding in 1979 [53], resistance of the EV-DNA complex to DNase, and transfer of DNA via EVs in bacteria in 1982 [54]. Subsequently, through studies that showed the ability of EVs to transport their DNA cargo into host cells [55,56], others have reported that double-stranded DNA (dsDNA) in exosomes can be used as a biomarker in cancer detection [26,57].

Following the identification of EVs as carriers of DNA, RNA, and protein, the literature on EVs expanded substantially, with considerable attention given to the protein and RNA 
cargos. More recently, EV DNA, another important EV biomolecule, has emerged as a relevant and valuable material for cancer biology.

\section{Characteristics of Extracellular Vesicle-Derived DNA}

EVs exist in various forms, such as single vesicles, double vesicles, double-membrane vesicles, and multilayer vesicles [58,59]. EV DNAs exist in both single strand [60] and double-strand forms [61,62], along with the nuclear protein histone [63], enclosed in EVs (Figure 1). The presence of dsDNA in single vesicles and multilayer vesicles was observed using immuno-EM (Figure 2). Genomic DNA, mitochondrial DNA (mtDNA), and plasmid DNA have all been identified inside exosomes, microvesicles, and apoptotic bodies [63-68]. Apart from DNA enclosed within EV, it can be attached to the outer surface of EV, or both $[35,63,64,69]$ (Figure 1). EV DNA can be detected in almost all body fluids, including the blood [57], urine [70], saliva [71], pleural effusion [10], BALF [15], ascites [72], and gastric juice [73] (Figure 3). The presence of dsDNA in EVs is well established; however, some reports have suggested that exosomes do not carry DNA [74]. This inconsistency in the results on the presence and absence of DNA can be attributed to the preparation method and size of the isolated EVs. If the isolation method is too rigorous, it may cause the loss of DNA-containing vesicles, leading to low DNA detection [75]. DNA is unlikely to exist inside an EV in the naked form; it exists in a nucleosome or supercoiled form, which would enable the packaging of large dsDNA into EVs such as oncosomes. In addition, considering that the size of the nucleosome is $11 \mathrm{~nm}$ [76], it is reasonable to assume that long dsDNA would likely not be present in EVs smaller than $50 \mathrm{~nm}$ in diameter. Several studies have utilized immuno-EM with anti-dsDNA to evaluate EVs isolated using size-based methods, and have identified them as exosomes [26,77]; basing the identification only on size (smaller than $200 \mathrm{~nm}$ ) may not be correct. In a 2017 study by Takahashi et al. [78], DNA was observed in intraluminal vesicles (ILVs) inside multivesicular endosomes (MVEs) and not exosomes. Therefore, the presence of DNA in excreted exosomes remains controversial and will continue to be controversial until the development of a method for isolating pure exosomes or microvesicles.
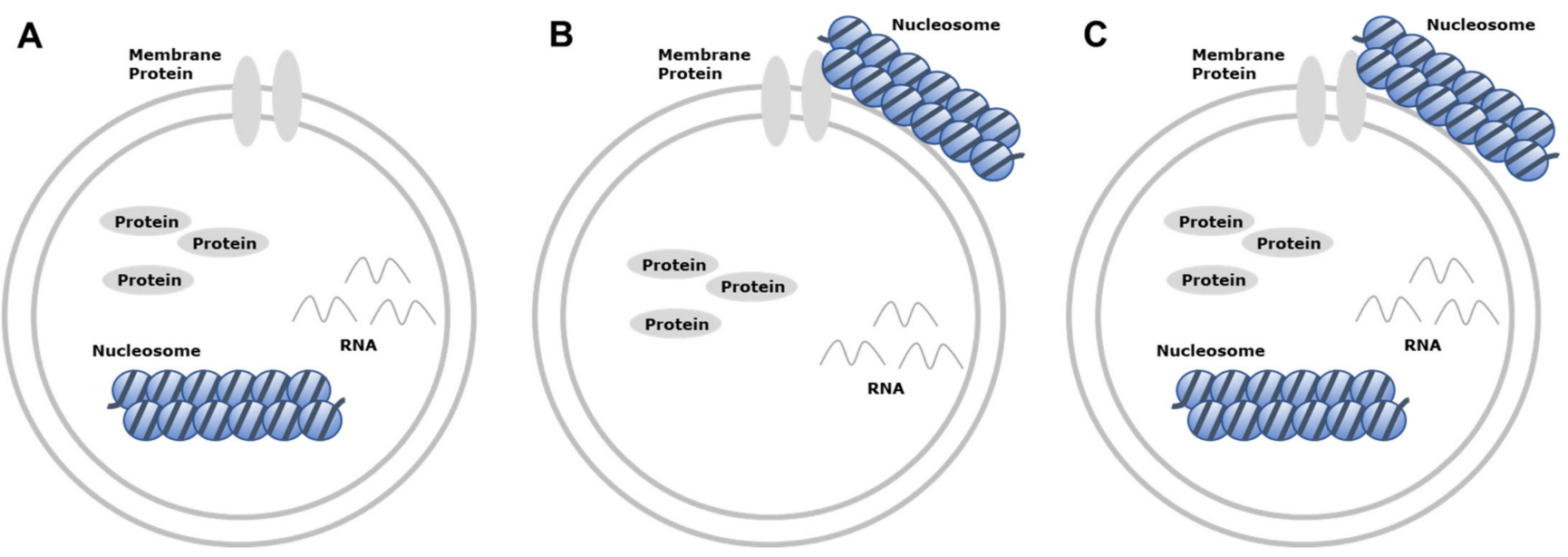

Figure 1. Characterization of DNA-loaded EVs. (A) DNA can be enclosed within EVs, (B) attached to the outer surface of $\mathrm{EV}$, or $(\mathbf{C})$ enclosed and attached to the outer surface. EV-extracellular vesicle. 

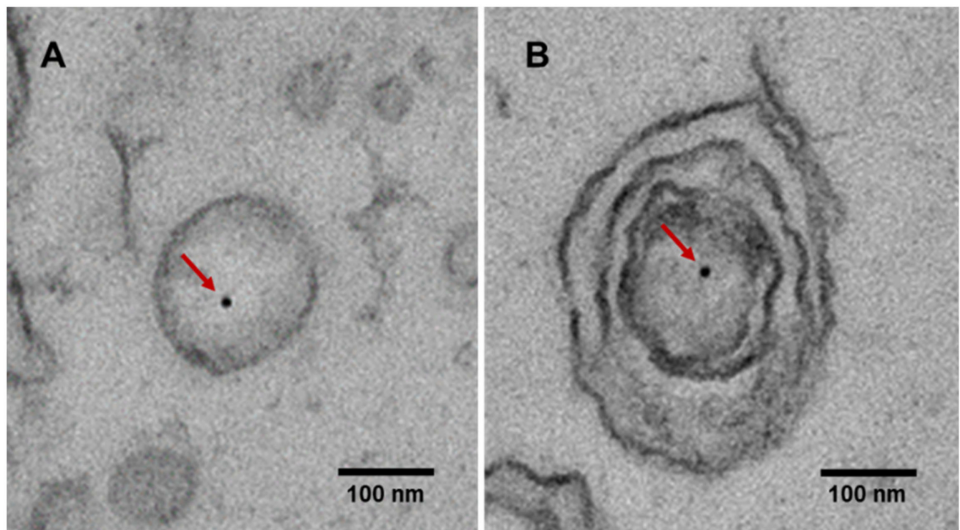

Figure 2. Detection of dsDNA in BALF EVs using immuno-EM. (A) Single vesicle and (B) multilayer vesicle. The solid black dots indicate DNA (indicated by red arrows). dsDNA—double-stranded DNA; BALF—bronchoalveolar lavage fluid; EV—extracellular vesicle; EM—electron microscopy.

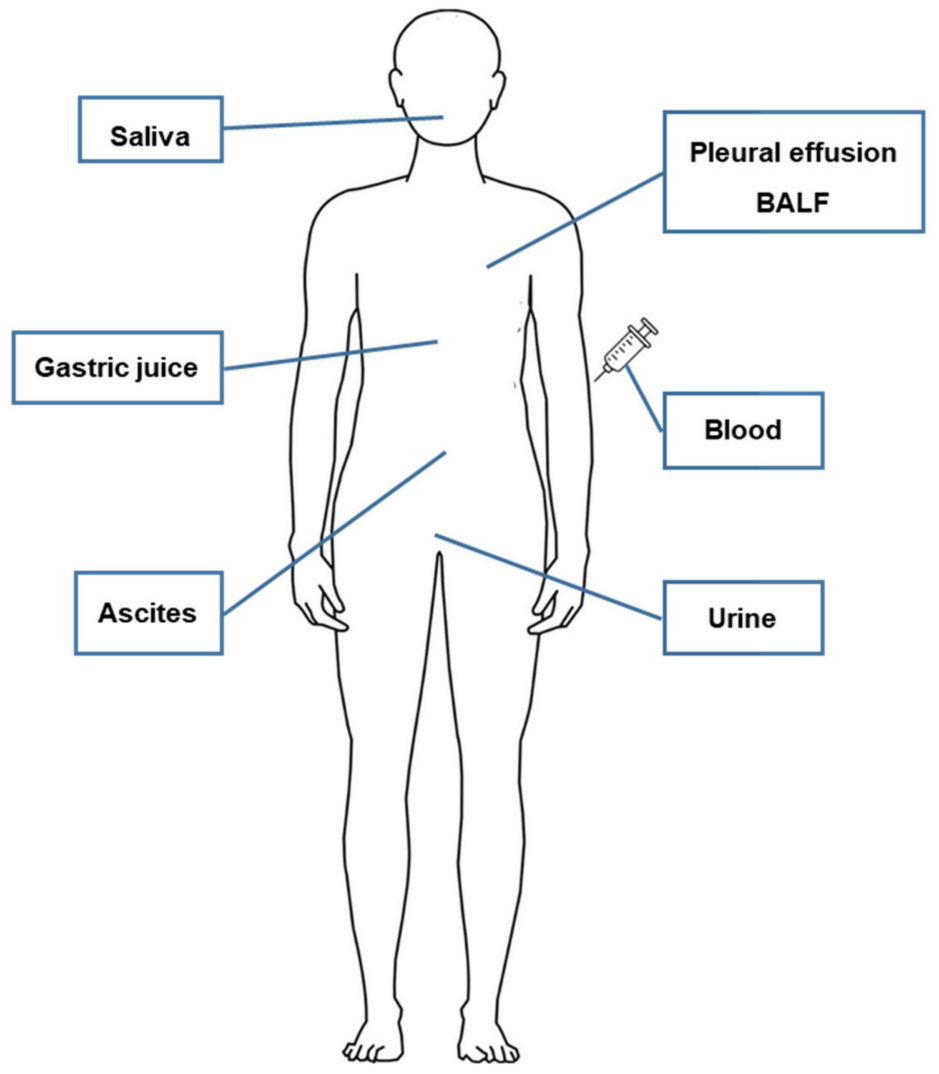

Figure 3. Body fluids as a source of DNA derived from EV. EV-extracellular vesicle; BALFbronchoalveolar lavage fluid.

Nonetheless, it is clear that DNA extracted from all categories of EVs is the latest and most promising biomarker for identifying tumor presence and complexity $[79,80]$. The size of dsDNA found in EVs ranges from $\sim 100 \mathrm{bp}$ to $20 \mathrm{kbp}$ [79], which can represent the entire genome and reflect the mutational status of tumor parental cells $[15,26,81]$. The EV nucleic acid (EV NA) population includes DNA and RNA of mutant or wild-type, and from this population, the target biomarker EV NA is detected more efficiently [82]. In addition, not using DNase in the DNA extraction process would increase the overall detection of mutant DNA, as this would include mutants from EV DNA and residual cfDNA in the sample [83-85]. 
Different studies and research teams have used various methods of EV isolation and DNA extraction that could impact DNA extraction efficiency. According to one study, adding polyethylene glycol improved general EV DNA isolation [86]. Additionally, the development of a microfluidic platform demonstrated that a new method can be used to successfully isolate EV DNA and monitor the residual or recurrent tumor presence in pancreatic cancer [87].

\section{Extracellular Vesicle-Derived DNA Stability and Mutant Detection}

EVs have been proven to increase the stability of their contents by protecting them from digestive enzymes and other biological fluids until the contents reach their target; hence, they play a role in enhancing the availability of bioactive compounds. [88,89]. Osteikoetxea $X$ et al. [90] showed that EVs are resistant to detergent lysis owing to a liquidordered phase membrane. The stability of EVs extends beyond the isolation process, as they are in their optimal state even after isolation, as demonstrated by several studies. Isolated EVs can be safely stored for up to one year at temperatures below $-80{ }^{\circ} \mathrm{C}$ with no coagulation $[91,92]$ and up to 3 months at $-0^{\circ} \mathrm{C}$ [93]. In addition, almost all types of exosomes contained in biofluids can be stored for up to 5 days at $4{ }^{\circ} \mathrm{C}$ in a glass bottle [91]. Kumeda et al. [94] showed that the integrity of isolated exosomes was stable for up to 20 months when stored at $4{ }^{\circ} \mathrm{C}$ and 28 days when stored at $4{ }^{\circ} \mathrm{C}$ as whole saliva.

Moreover, the EV DNA from the serum remained stable for 1 week at $4{ }^{\circ} \mathrm{C}, 1$ day at room temperature, and even after repeated freeze-thaw cycles [39]. In contrast, freefloating and circulating DNAs in body fluids, cfDNAs, undergo non-specific degradation $[37,38]$. The stability and abundance of EV DNA make it a good source for highly sensitive detection of DNA mutations by liquid biopsy [10,15,95-97]. EGFR genotyping using EV DNA derived from pleural effusion in lung cancer is a good example. Compared with cfDNA liquid biopsy and tissue genotyping, EV DNA genotyping resulted in $100 \%$ agreement in EGFR-tyrosine kinase inhibitor (TKI)-naïve patients. When detecting a biomarker EGFR mutation for EGFR-TKI resistance, T790M, using EV DNA even surpassed cell blocks or cfDNA in detection sensitivity [10]. In another study, the sensitivity and specificity of BALF EV-based EGFR genotyping were high and showed an even better mutation detection rate than tissue- or cytology-based typing of patients with lung cancer [98].

Collectively, these results show the stability and sensitivity of EV DNA-based genotyping and demonstrate that the highly promising liquid biopsy method is particularly efficient for patients that require repeated diagnosis throughout the disease progression. However, one must not forget that although EVs and their DNAs are stable, the structural and physicochemical properties could change because of several external factors such as pressure, freeze-thaw cycles, nature of the solvent, and storage duration [88].

\section{Methylation of Extracellular Vesicle-Derived DNA}

Apart from tumor-specific changes in its sequence, tumor DNA exhibits distinctive epigenetic marks and changes in DNA methylation [99]. Analysis of specific patterns of DNA methylation is attracting attention as a potential biomarker for the detection and diagnosis of diseases such as cancer $[100,101]$. Several studies have evaluated the methylation of EV DNA and demonstrated similarities in methylation profiles between gDNA and EV DNA in murine melanoma cells [26]; the gastric juice in patients with gastric cancer $[73,102]$; and the serum in patients with breast cancer and melanoma [103], metastatic castration-resistant prostate cancer [104], diffuse large B-cell lymphoma [105], and glioblastoma [106] (Table 1). These studies have revealed differences in the methylation of cancer cells and normal cells, and suggested methylation as a biomarker. Specifically, studies in patients with gastric cancer demonstrated methylation in SOX17 [73] and BARHL2 with a high sensitivity and specificity [102]. EV DNA purified from the serum of patients with breast cancer and melanoma cancer was hypomethylated compared with that from normal patients [103]. In addition, the significant genes in metastatic castration-resistant prostate cancer, GSTP1, RASSF1A, and SLFN11, were identified to be DNA methylated in both CTCs 
and exosomes [104]. In the case of diffuse large B-cell lymphoma, the promoter regions of $C D K N 2 A$ and $C D K N 2 B$ were determined to be methylated in both plasma exosomes and primary tumor tissue [105]. A study on glioblastoma demonstrated that EVs with an origin close to their corresponding cells are more likely to correctly identify the methylation class of the parental cells and original tumors [106].

Table 1. Summary of methylation analysis performed with EV DNA.

\begin{tabular}{|c|c|c|c|c|}
\hline Source of EV (Sample Size) & EV Type (Size) & Isolation Method of EV & Methylation Analysis (Gene) & Reference \\
\hline Murine melanoma cell B16-F10 & Exosome & $\begin{array}{c}\text { Differential ultracentrifugation } \\
\text { and filtration }\end{array}$ & Dot blot analysis & [26] \\
\hline $\begin{array}{l}\text { Gastric juice from patients with } \\
\text { gastric cancer }(n=20)\end{array}$ & Exosome $(30-100 \mathrm{~nm})$ & ExoQuick-TC & $\begin{array}{l}\text { Bisulfite pyrosequencing } \\
\text { (SOX17) }\end{array}$ & [73] \\
\hline $\begin{array}{l}\text { Gastric juice, gastric cancer } \\
(n=20) \text {, and non-gastric cancer } \\
(n=10)\end{array}$ & Exosome & ExoQuick-TC & $\begin{array}{l}\text { Bisulfite pyrosequencing } \\
\text { (BARHL2) }\end{array}$ & [102] \\
\hline $\begin{array}{l}\text { Serum; normal }(n=7) \text {, breast } \\
\text { cancer }(n=5) \text {, and melanoma } \\
\qquad(n=4)\end{array}$ & EV $(30-250 \mathrm{~nm})$ & $\begin{array}{c}\text { Total Exosome isolation } \\
\text { reagent }\end{array}$ & $\begin{array}{l}\text { ELISA-based global DNA } \\
\text { methylation analysis and } \\
\text { microelectrode device }\end{array}$ & [103] \\
\hline $\begin{array}{l}\text { Saliva from patients with gingivitis } \\
(n=7) \text { and healthy individuals } \\
\qquad(n=5)\end{array}$ & Small EV $(<200 \mathrm{~nm})$ & $\begin{array}{c}\text { Differential ultracentrifugation } \\
\text { and filtration or size exclusion } \\
\text { chromatography }\end{array}$ & $\begin{array}{c}\text { Quantitative } \\
\text { methylation-specific PCR } \\
(I L-6, T N F-\alpha, I L-1 \beta, I L-8, \\
\text { and } I L-10)\end{array}$ & {$[71]$} \\
\hline $\begin{array}{l}\text { Plasma from patients with prostate } \\
\text { cancer }(n=62) \text { and healthy } \\
\text { individuals }(n=10)\end{array}$ & Exosome & exoRNeasy Maxi kit & $\begin{array}{c}\text { Real-time methylation-specific } \\
\text { PCR (GSTP1, RASSF1A, and } \\
\text { SLFN11) }\end{array}$ & [104] \\
\hline $\begin{array}{l}\text { Plasma from patients with } \\
\text { lymphoma }(n=21) \text { and healthy } \\
\text { individuals }(n=21)\end{array}$ & Exosome $(40-120 \mathrm{~nm})$ & $\begin{array}{l}\text { Differential ultracentrifugation } \\
\text { and filtration }\end{array}$ & $\begin{array}{c}\text { Methylation-specific PCR } \\
(C D K N 1 A, C D K N 1 B, C D K N 2 A, \\
\text { and } C D K N 2 B) \text { or dot blot } \\
\text { analysis }\end{array}$ & [105] \\
\hline Glioblastoma stem-like cell $(n=8)$ & $\mathrm{EV}$ & $\begin{array}{l}\text { Differential ultracentrifugation } \\
\text { and filtration or size exclusion } \\
\text { chromatography }\end{array}$ & $\begin{array}{c}\text { Infinium methylation EPIC } \\
\text { arrays }\end{array}$ & [106] \\
\hline $\begin{array}{l}\text { Saliva from patients with gingivitis } \\
(n=7) \text { and periodontitis }(n=8) \\
\text { and healthy individuals }(n=7)\end{array}$ & Small EV $(<200 \mathrm{~nm})$ & $\begin{array}{l}\text { Size exclusion } \\
\text { chromatography }\end{array}$ & $\begin{array}{c}\text { Global DNA methylation } \\
\text { assay }\end{array}$ & [107] \\
\hline
\end{tabular}

EV—extracellular vesicle; EV DNA—EV-derived DNA.

Gingivitis-related methylation has been evaluated using ultracentrifugation and size exclusion chromatography for EV DNA derived from the saliva; no significant difference was observed between the healthy and gingivitis samples [71]. In another study on gingivitis and periodontitis, periodontitis-associated EV DNA exhibited significantly increased global 5-methylcytosine $(5 \mathrm{mC})$ and N6-methyl-2'-deoxyadenosine (m6dA) modification in the DNA, while the gDNA showed no difference between the gingivitis and normal samples [107].

These findings suggest that the methylation analysis of EV DNA can serve as a useful biomarker for the detection of various diseases, especially in the diagnosis of cancer. However, the source of EV DNA, sample collection, DNA extraction method, and the type of disease appear to affect methylation detection.

\section{Mechanism of DNA Loading onto EV and Transfer of EV-Derived DNA}

Several functional reasons have been suggested for the loading of DNA onto EVs. For instance, cells can excrete harmful cytoplasmic DNA using EVs containing chromosome fragments to maintain cellular homeostasis and prevent viral hijacking of the cellular machinery [78]. In normal cells, gDNA is mainly confined to the cell nucleus, and gDNA generally does not interact with the cytoplasmic multivesicular bodies (MVB) that produce exosomes [78]. Conversely, EVs contain gDNA and nuclear proteins [72], as well as contents associated with cell senescence and stimulation of the STING inflammatory pathway [78]. The inhibition of exosome secretion results in the accumulation of nuclear DNA in the cytoplasm, thereby activating the cytoplasmic DNA-sensing machinery [78]. The detection of gDNA predominantly in EVs derived from cancer cells rather than healthy 
cells could be caused by the loading of nuclear components, including micronuclei, into EVs [72]. Although this phenomenon is relatively well known, the mechanisms remain poorly understood.

To confirm the presence and quantify the amount of gDNA in exosomes, tetraspanins are most often used as protein markers for sorting out exosomes, and dsDNA-binding dye is used for quantifying the percentage of DNA-positive exosomes [72]. A previous study illustrated the involvement of micronuclei-extra-nuclear bodies that contain damaged chromosome fragments or whole chromosomes generated when the cell nucleus fails to properly segregate nuclear material. This result shows that micronucleus-originated DNA are loaded into exosomes through a CD63-mediated DNA shuttle. They knocked down CD63 in ovarian cancer cells, which prevented the loading of micronucleus-originated DNA into exosomes [72]. An earlier study suggested another pathway involving the depletion of the nuclear envelope protein emerin, a well-known feature of cancer, which causes nuclear shape instability and shedding of nuclear-derived EVs that contain genomic material as a possible EV DNA-loading mechanism [108] (Figure 4). In addition, the biogenesis of oncogenes containing EVs in brain tumor cells may be independent of Rb/TP53 and acid sphingomyelinase (ASMase) pathways [62], both of which are vesiculation pathways of exosomes [109] and microvesicle biogenesis [110], respectively.

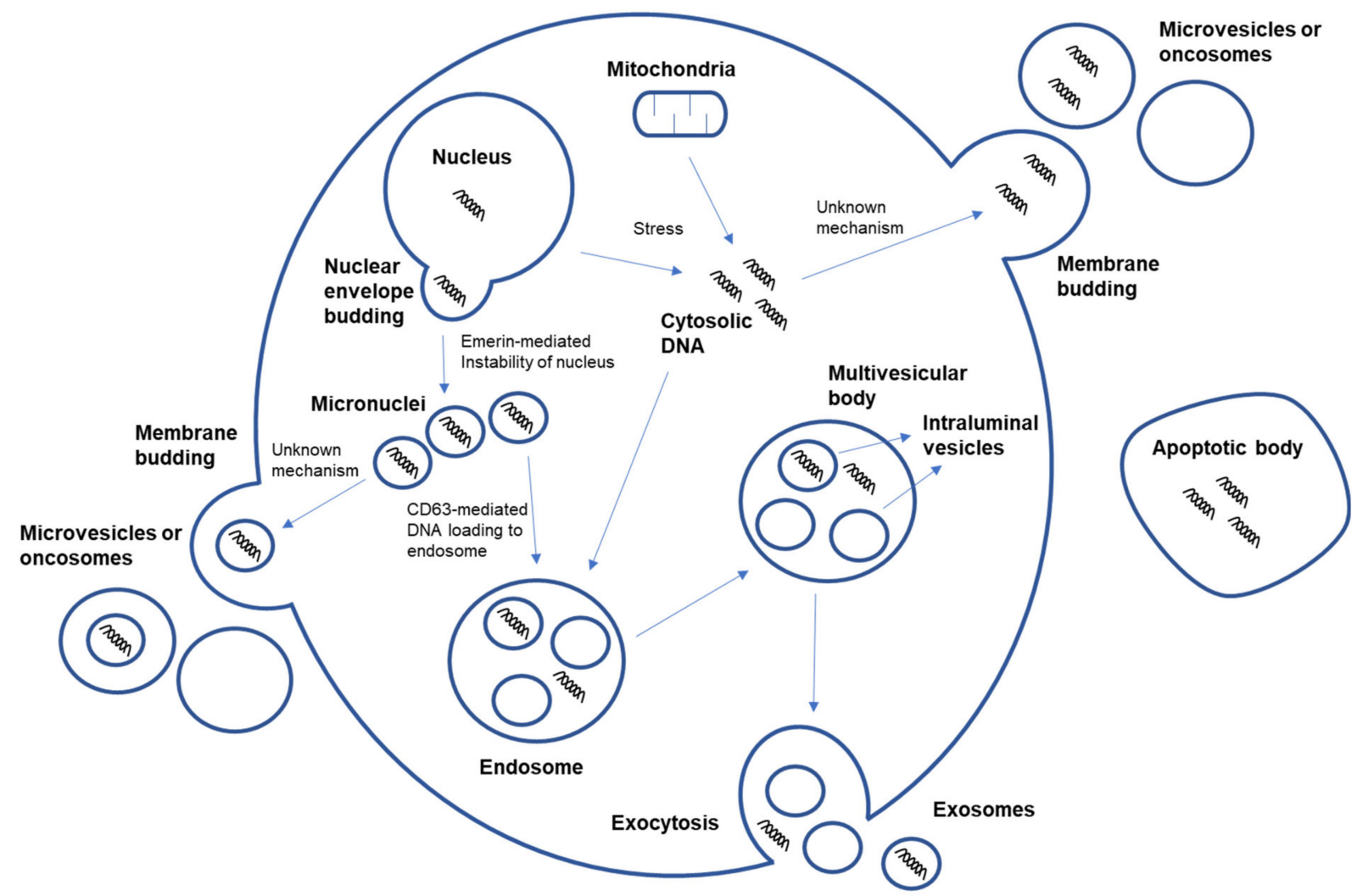

Figure 4. DNA loading into EVs via various mechanisms. DNA can be loaded into EVs through a CD63-mediated DNA shuttle or emerin-mediated nucleus instability and shedding. Other possible unknown mechanisms could include the loading of cytosolic DNA that originated from the nucleus and mitochondria by oxidative stress. EV-extracellular vesicle.

An additional possibility is the loading of DNA into tumor-derived exosomes in a manner similar to the mechanism of early vital NETosis, a form of neutrophil-specific cell death characterized by the expulsion of DNA that forms web-like structures referred to as neutrophil extracellular traps (NETs) against bacterial infection [111]. The mechanisms of dsDNA loading onto EVs and the secretion of EVs appear to be similar to the loading and secretion of virus dsDNA via EVs [112,113]. 
One of the functions of EVs is the transmission of signals from donors, providing a mechanism that can directly alter signaling in the recipient cell, leading to the exchange of complex information [114,115]. Although EVs vary in size, composition, and abundance, they often contain functional transmembrane proteins, lipids, mRNAs, and microRNAs $[30,116]$. Several reports have raised doubts about the direct loading of nucleic acids into EVs and their functionality when taken up by recipient cells. These studies showed that siRNA transfection into EVs by electroporation induces the formation of insoluble siRNA aggregates [117], and EVs loaded with plasmid DNAs by electroporation delivered DNA to recipient cells; however, they were not functionally active [118]. In addition, testing with human embryonic kidney cell-derived exosomes, transfected mRNAs, siRNAs, and plasmid DNA failed to induce or downregulate the protein expression in recipient cells [119].

Conversely, many recent studies have shown EV-mediated intercellular communication by horizontal gene transfer (HGT) with pre-existing mutations, demonstrating that EV DNAs are functional when transferred to recipient cells [120] (Table 2). Recipient cells receive genes through the fusion or internalization of EVs, and the biomaterial contents of EVs are transported into the nuclear compartment through nuclear envelope invagination-associated late endosomes [121,122]. This would require interactions between tumor cells and the microenvironment, including the composite of heterogeneous cells that populate the tumor. According to previous reports, other types of EVs can mediate ssDNA and dsDNA transfers. Most intercellular transfer of oncogenic DNA has been attributed to the uptake of exosomes, microvesicles, and apoptotic bodies [60,62,123]. For example, integrated viral genes are horizontally transferred by the uptake of DNA from apoptotic bodies [124]. Tumor DNA is horizontally transferred by the uptake of apoptotic bodies. The phagocytosis of apoptotic bodies derived from oncogenic $\mathrm{H}$-ras- and human $c$-myc-transfected rat fibroblasts resulted in the development of a tumorigenic phenotype in mouse cells undergoing malignant transformation. The DNA transfer was confirmed by fluorescence in situ hybridization analysis, which showed the presence of donor DNA in the recipient cells [123]. A study demonstrated that donor cell EV gDNA can be transferred to recipient cells, and it can increase the mRNA and protein expression and even change function. Moreover, the transferred EV gDNA has pathophysiological significance, as a $\mathrm{BCR} / \mathrm{ABL}$ hybrid gene involved in the pathogenesis of leukemia could be transferred from leukemia cells to human embryonic kidney cells or neutrophils through EVs [61]. Another study showed that the human $H$-ras oncogene in rat epithelial cells increased the production of EVs, which can be transiently transferred to recipient cells, increasing the recipient-cell proliferation [62]. In addition, mouse cardiomyocyte EV DNA transfer into target fibroblasts was proven, where DNA stains were observed in the fibroblast cytosol and nucleus. A total of 333 gene expressions were altered in the fibroblasts transfected with EVs [125].

Bacterial outer membrane vesicles (OMVs) can deliver DNA to other bacteria over long distances [55]. OMVs even have the ability to deliver DNA into other species of bacteria and eukaryotic host cells [56]. A study using bone marrow-derived mesenchymal stromal cells (MSCs) and foreign DNA of Arabidopsis thaliana demonstrated that EVs were capable of HGT between MSCs [126]. Furthermore, in patients with breast cancer, cancer-associated fibroblasts (CAFs) package mtDNA into EVs, which can contribute to the upregulation of mitochondrial genes required for oxidative phosphorylation when taken up by hormone therapy (HT)-resistant breast cancer cells. Specifically, the treatment of HT-naive cells or HT-treated metabolically dormant cells with CAF-derived EVs harboring mtDNA promoted an escape from metabolic quiescence and the development of drug resistance both in vitro and in vivo [127]. This shows that EV-mediated HGT was not limited to gDNA. The first study exploring the mechanism of HGT by exosomes suggests that HGT occurs in double-strand break repair through genome editing [128]. These results suggest that the EV-mediated lateral transfer of DNA between eukaryotic cells may result in aneuploidy and the accumulation of genetic factors, leading to tumor formation, 
which is a driving force behind mammalian genome evolution. Further investigation into the molecular mechanisms of EV-DNA-mediated gene transformation could open up several opportunities for cancer biology and therapeutics, and warn us of new risks for the leading-edge technology.

Table 2. Research on the transfer of EV DNA.

\begin{tabular}{|c|c|c|c|c|c|c|}
\hline Donor Cells & Recipient Cells & EV Type (Size) & $\begin{array}{c}\text { Isolation } \\
\text { Method of EV }\end{array}$ & $\begin{array}{l}\text { Method of EV } \\
\text { Transfer }\end{array}$ & $\begin{array}{c}\text { Effect of EV DNA } \\
\text { Transfer }\end{array}$ & Reference \\
\hline $\begin{array}{l}\text { EBV-carrying } \\
\text { transformed } \\
\text { lymphoid cells }\end{array}$ & $\begin{array}{l}\text { Human fibroblast, } \\
\text { macrophage, or } \\
\text { bovine aortic } \\
\text { endothelial cell }\end{array}$ & Apoptotic body & & Co-culture & $\begin{array}{l}\text { EBV-DNA and gDNA } \\
\text { transfer to recipient cells } \\
\text { via apoptotic bodies }\end{array}$ & [124] \\
\hline $\begin{array}{l}H \text {-ras and } c-m y c \\
\text { transformed rat } \\
\text { embryonic } \\
\text { fibroblasts }\end{array}$ & $\begin{array}{l}\text { Mouse embryonic } \\
\text { fibroblast }\end{array}$ & Apoptotic body & & Co-culture & $\begin{array}{l}\text { Oncogenes of donor cell } \\
(H \text {-ras and } c \text {-myc) cause } \\
\text { transformation of the } \\
\text { recipient cells via } \\
\text { apoptotic bodies }\end{array}$ & [123] \\
\hline $\begin{array}{c}\text { Mouse } \\
\text { cardiomyocytes } \\
\text { HL-1 }\end{array}$ & $\begin{array}{c}\text { Fibroblasts NIH } \\
\text { 3T3 }\end{array}$ & Microvesicle & $\begin{array}{l}\text { Differential ultra- } \\
\text { centrifugation }\end{array}$ & $\begin{array}{c}\text { Incubation of } \\
\text { fibroblasts with } \\
\text { EV }\end{array}$ & $\begin{array}{l}\text { EV DNA transfer to } \\
\text { fibroblasts }\end{array}$ & [125] \\
\hline $\begin{array}{c}\mathrm{AT}_{1} \text { receptor } \\
\text { transfected } \\
\text { HEK293 cells or } \\
\text { VSMC or } \\
\text { leukemia cells, } \\
\text { K562 }\end{array}$ & $\begin{array}{l}\text { HEK293 or } \\
\text { human } \\
\text { neutrophil }\end{array}$ & EV $(30-1000 \mathrm{~nm})$ & $\begin{array}{l}\text { Differential ultra- } \\
\text { centrifugation }\end{array}$ & $\begin{array}{l}\text { Incubation of } \\
\text { HEK293 or } \\
\text { human } \\
\text { neutrophils with } \\
\text { EVs }\end{array}$ & $\begin{array}{l}\mathrm{AT}_{1} \text { receptor or } B C R / A B L \\
\text { hybrid gene transfer via } \\
\mathrm{EV} \text { and expression on } \\
\text { recipient cells }\end{array}$ & [61] \\
\hline $\begin{array}{c}\text { H-ras } \\
\text { transformed rat } \\
\text { epithelial cells, } \\
\text { RAS-3 }\end{array}$ & $\begin{array}{l}\text { Rat fibroblasts } \\
\text { RAT-1 }\end{array}$ & EV $(100 \mathrm{~nm})$ & $\begin{array}{l}\text { Differential ultra- } \\
\text { centrifugation } \\
\text { and filtration }\end{array}$ & $\begin{array}{l}\text { Incubation of } \\
\text { fibroblasts with } \\
\text { EVs }\end{array}$ & $\begin{array}{l}\text { Transfer of oncogenes of } \\
\text { donor cells to recipient } \\
\text { cells via EV }\end{array}$ & [62] \\
\hline $\begin{array}{l}\text { Arabidopsis } \\
\text { thaliana-plasmid- } \\
\text { transduced } \\
\text { hMSC }\end{array}$ & hMSC & $\begin{array}{l}\text { Small EV } \\
(50-150 \mathrm{~nm})\end{array}$ & $\begin{array}{l}\text { Differential ultra- } \\
\text { centrifugation }\end{array}$ & $\begin{array}{l}\text { Incubation of } \\
\text { hMSC with EVs }\end{array}$ & $\begin{array}{c}\text { Horizontal plant DNA } \\
\text { transfer to eukaryotic cells } \\
\text { via EV }\end{array}$ & [126] \\
\hline $\begin{array}{l}\text { Pseudomonas } \\
\text { aeruginosa }\end{array}$ & $\begin{array}{c}\text { Human } \\
\text { adenocarcinoma } \\
\text { A549 }\end{array}$ & OMV ( 20 nm) & $\begin{array}{l}\text { Differential ultra- } \\
\text { centrifugation, } \\
\text { filtration, and } \\
\text { density gradient } \\
\text { ultracentrifuga- } \\
\text { tion }\end{array}$ & $\begin{array}{l}\text { Incubation of } \\
\text { lung epithelial } \\
\text { cells with OMV }\end{array}$ & $\begin{array}{l}\text { OMV-derived DNA is } \\
\text { detected in the nuclear } \\
\text { fraction of epithelial cell }\end{array}$ & [56] \\
\hline $\begin{array}{l}\text { Murine } \\
\text { cancer-associated } \\
\text { fibroblasts from } \\
\text { xenograft }\end{array}$ & $\begin{array}{c}\text { Hormonal } \\
\text { therapy-naïve } \\
\text { breast cancer cell }\end{array}$ & $\mathrm{EV}(\sim 140 \mathrm{~nm})$ & $\begin{array}{l}\text { Differential ultra- } \\
\text { centrifugation }\end{array}$ & $\begin{array}{c}\text { Injecting mCAF } \\
\text { EV into } \\
\text { tumor-bearing } \\
\text { mouse or } \\
\text { incubation of } \\
\text { breast cancer cells } \\
\text { with EV }\end{array}$ & $\begin{array}{l}\text { Transfer of therapy } \\
\text { resistance to } \\
\text { therapy-sensitive cells via } \\
\text { mtDNA from EV in vivo } \\
\text { and in vitro }\end{array}$ & [127] \\
\hline
\end{tabular}

EV—extracellular vesicle; EV DNA—EV-derived DNA; EBV—Epstein-Barr virus; VSMC—vascular smooth muscle cells; hMSC—human mesenchymal stem cell; OMV—outer membrane vesicles; mCAF—-murine cancer-associated fibroblasts; mtDNA—mitochondrial DNA.

\section{NGS Analysis Using Extracellular Vesicle-Derived DNA}

In 2014, three independent studies profiled dsDNA isolated from EVs using NGS, verifying the possibility for clinical use for the first time $[26,57,62]$. Since then, several research groups have performed whole-genome sequencing (WGS), whole-exome sequencing (WES), and targeted NGS for the last seven years (Table 3). The revolutionary finding that EVs contain protected dsDNA opened new opportunities for their application as a more concentrated and better-preserved source of cancer-derived genomic material, as an alternative to cfDNA [129]. Moreover, EVs contain gDNA originating from long dsDNA, and NGS analysis is possible without the need for deep sequencing or barcoding NGS [41]. 
Table 3. Summary of NGS analysis performed with EV DNA.

\begin{tabular}{|c|c|c|c|c|c|c|c|}
\hline NGS Type & $\begin{array}{c}\text { Source of EV (Sample } \\
\text { Size) }\end{array}$ & EV Type (Size) & $\begin{array}{c}\text { Isolation Method } \\
\text { of EV }\end{array}$ & $\begin{array}{l}\text { Mean } \\
\text { Depth }\end{array}$ & $\begin{array}{l}\text { Subjects of } \\
\text { Comparison }\end{array}$ & $\begin{array}{l}\text { Number of } \\
\text { Targeted } \\
\text { Genes }\end{array}$ & Reference \\
\hline WGS & $\begin{array}{l}\text { Plasma of healthy } \\
\text { humans }(n=30)\end{array}$ & EV & $\begin{array}{c}\text { Differential } \\
\text { ultracentrifugation }\end{array}$ & & & & {$[61]$} \\
\hline WGS & $\begin{array}{l}\text { Serum of patients with } \\
\text { pancreatic cancer }(n= \\
\text { 2) }\end{array}$ & Exosome & $\begin{array}{l}\text { Differential } \\
\text { ultracentrifugation } \\
\text { and filtration }\end{array}$ & $4 \times$ & $\begin{array}{l}\text { CNV of tumor } \\
\text { DNA and } \\
\text { exoDNA }\end{array}$ & & [57] \\
\hline WGS & $\begin{array}{l}\text { Murine melanoma cells, } \\
\text { B16-F10 }\end{array}$ & Exosome & $\begin{array}{l}\text { Differential } \\
\text { ultracentrifugation } \\
\text { and filtration }\end{array}$ & & $\begin{array}{l}\text { CNV of } \\
\text { exoDNA }\end{array}$ & & [26] \\
\hline WGS & $\begin{array}{c}\text { Human H-ras } \\
\text { transformed rat } \\
\text { intestinal epithelial } \\
\text { cells, RAS-3 }\end{array}$ & EV (100 nm) & $\begin{array}{c}\text { Differential } \\
\text { ultracentrifugation } \\
\text { and filtration }\end{array}$ & $\sim 7 \times$ & $\begin{array}{l}\text { CNV of EV } \\
\text { DNA }\end{array}$ & & [62] \\
\hline WGS & $\begin{array}{l}\text { Pleural effusion }(n=1) \\
\text { and plasma }(n=2) \text { of } \\
\text { patients with } \\
\text { pancreaticobiliary } \\
\text { cancer }\end{array}$ & Exosome & $\begin{array}{l}\text { Differential } \\
\text { ultracentrifugation } \\
\text { and filtration }\end{array}$ & $12-35 \times$ & $\begin{array}{l}\text { CNV, SNV, } \\
\text { gene fusions, } \\
\text { and mutational } \\
\text { signature of } \\
\text { tumor DNA } \\
\text { (tissue) and } \\
\text { exoDNA }\end{array}$ & & [40] \\
\hline WGS & $\begin{array}{c}\text { Human bone } \\
\text { marrow-derived MSC } \\
(n=2)\end{array}$ & $\begin{array}{l}\text { Small EV } \\
(50-150 \mathrm{~nm})\end{array}$ & $\begin{array}{c}\text { Differential } \\
\text { ultracentrifugation }\end{array}$ & & $\begin{array}{l}\text { CNV of EV } \\
\text { DNA }\end{array}$ & & [126] \\
\hline WGS & $\begin{array}{c}\text { Malaria } \\
\text { parasite-infected } \\
\text { human red blood cells }\end{array}$ & $\begin{array}{c}\mathrm{EV} \\
(50-350 \mathrm{~nm})\end{array}$ & $\begin{array}{c}\text { Differential } \\
\text { ultracentrifugation, } \\
\text { filtration, and } \\
\text { density gradient } \\
\text { ultracentrifugation } \\
\text { Differential }\end{array}$ & & $\begin{array}{l}\text { CNV of } \\
\text { malaria gDNA } \\
\text { and EV DNA }\end{array}$ & & [130] \\
\hline WGS & $\begin{array}{l}\text { Human fibroblasts, } \\
\text { TIG-3 }\end{array}$ & Exosome & $\begin{array}{l}\text { Differential } \\
\text { ultracentrifugation, } \\
\text { filtration, and } \\
\text { density gradient } \\
\text { ultracentrifugation }\end{array}$ & & $\begin{array}{l}\text { RPKM of } \\
\text { genomic DNA } \\
\text { and EV DNA }\end{array}$ & & [78] \\
\hline WGS & $\begin{array}{l}\text { Urine of patients with } \\
\text { urothelial bladder } \\
\text { carcinoma }(n=9)\end{array}$ & Exosome & ExoQuick-TC & $0.6 \times$ & $\begin{array}{l}\text { CNV of tumor } \\
\text { DNA and } \\
\text { urinary DNA } \\
\text { (cfDNA and } \\
\text { exoDNA) }\end{array}$ & & [70] \\
\hline WGS & $\begin{array}{l}\text { Serum of patients with } \\
\text { pheochromocytoma } \\
\text { and paragangliomas } \\
\text { and rat cells, PC12 }\end{array}$ & Exosome & $\begin{array}{c}\text { Differential } \\
\text { ultracentrifugation }\end{array}$ & & $\begin{array}{l}\text { SNP of tumor } \\
\text { DNA and } \\
\text { exoDNA }\end{array}$ & & [131] \\
\hline WGS & $\begin{array}{c}\text { Human prostate cancer } \\
\text { cells, PC3 }\end{array}$ & $\begin{array}{c}\text { Large EV } \\
(1.0-5.5 \mu \mathrm{m})\end{array}$ & $\begin{array}{c}\text { Differential } \\
\text { ultracentrifugation } \\
\text { and density } \\
\text { gradient } \\
\text { ultracentrifugation }\end{array}$ & $\sim 1.4 \times$ & $\begin{array}{l}\mathrm{CNV} \text { and } \\
\text { genomic rear- } \\
\text { rangements of } \\
\text { gDNA and EV } \\
\text { DNA }\end{array}$ & & [35] \\
\hline WGS & $\begin{array}{l}\text { Human } \\
\text { erythroleukemic cells, } \\
\text { TF-1, and mast cells, } \\
\text { HMC-1 }\end{array}$ & $\begin{array}{l}\text { Small EV } \\
(\sim 120 \mathrm{~nm})\end{array}$ & $\begin{array}{l}\text { Differential } \\
\text { ultracentrifugation } \\
\text { and density } \\
\text { gradient } \\
\text { ultracentrifugation }\end{array}$ & $\begin{array}{r}9.25- \\
15.88 \times\end{array}$ & $\begin{array}{l}\text { CNV of EV } \\
\text { DNA }\end{array}$ & & [63] \\
\hline WGS & $\begin{array}{l}\text { Plasma and ascites of } \\
\text { patients with ovarian } \\
\text { cancer }(n=3) \text { and } \\
\text { human ovarian cancer } \\
\text { cells, OVCAR-5 }\end{array}$ & Exosome & $\begin{array}{l}\text { Differential } \\
\text { ultracentrifugation } \\
\text { and filtration }\end{array}$ & $20 \times$ & $\begin{array}{l}\text { CNV and SNV } \\
\text { of tumor DNA } \\
\text { (tissue) and } \\
\text { exoDNA } \\
\text { (plasma and } \\
\text { ascites) }\end{array}$ & & {$[72]$} \\
\hline WGS & $\begin{array}{l}\text { Maternal plasma } \\
\qquad(n=20)\end{array}$ & $\mathrm{EV}(30-50 \mathrm{~nm})$ & ExoQuick & $0.25 \times$ & $\begin{array}{c}\text { cfDNA and EV } \\
\text { DNA }\end{array}$ & & [132] \\
\hline
\end{tabular}


Table 3. Cont.

\begin{tabular}{|c|c|c|c|c|c|c|c|}
\hline NGS Type & $\begin{array}{c}\text { Source of EV (Sample } \\
\text { Size) }\end{array}$ & EV Type (Size) & $\begin{array}{c}\text { Isolation Method } \\
\text { of EV }\end{array}$ & $\begin{array}{l}\text { Mean } \\
\text { Depth }\end{array}$ & $\begin{array}{c}\text { Subjects of } \\
\text { Comparison }\end{array}$ & $\begin{array}{l}\text { Number of } \\
\text { Targeted } \\
\text { Genes }\end{array}$ & Reference \\
\hline WGS & $\begin{array}{l}\text { Plasma of patients with } \\
\text { breast cancer }(n=1, \\
\text { serial samples }(\mathrm{X} 3))\end{array}$ & $\begin{array}{c}\text { EV } \\
(30-600 \mathrm{~nm})\end{array}$ & $\begin{array}{c}\text { Differential } \\
\text { ultracentrifugation }\end{array}$ & $1 \times$ & $\begin{array}{l}\text { CNV of tumor } \\
\text { DNA (FFPE), } \\
\text { ctDNA, and } \\
\text { EV DNA }\end{array}$ & & [133] \\
\hline WGS & $\begin{array}{l}\text { Plasma of patients with } \\
\text { tongue base squamous } \\
\text { cell carcinoma }(n=3) \\
\text { and cutaneous } \\
\text { squamous cell } \\
\text { carcinoma }(n=2)\end{array}$ & EV (215 nm) & $\begin{array}{c}\text { Differential } \\
\text { ultracentrifugation }\end{array}$ & $0.5-1 \times$ & $\begin{array}{l}\text { CNV of tumor } \\
\text { DNA (FFPE) } \\
\text { and EV DNA }\end{array}$ & & [134] \\
\hline WES & $\begin{array}{l}\text { Pleural effusion }(n=1) \\
\text { and plasma }(n=2) \text { of } \\
\text { patients with } \\
\text { pancreaticobiliary } \\
\text { cancer }\end{array}$ & Exosome & $\begin{array}{l}\text { Differential } \\
\text { ultracentrifugation } \\
\text { and filtration }\end{array}$ & $133-490 \times$ & $\begin{array}{l}\text { SNV and } \\
\text { mutational } \\
\text { signature of } \\
\text { tumor DNA } \\
\text { (tissue) and } \\
\text { exoDNA }\end{array}$ & & [40] \\
\hline WES & $\begin{array}{l}\text { Plasma of patients with } \\
\text { neuroblastoma }(n=19)\end{array}$ & Exosome & $\begin{array}{l}\text { Exo-RNeasy } \\
\text { serum/plasma } \\
\text { midi kit }\end{array}$ & $110 \times$ & $\begin{array}{l}\text { SNV and TMB } \\
\text { of tumor DNA } \\
\text { (FFPE) and } \\
\text { exoDNA } \\
\text { (plasma) }\end{array}$ & & [135] \\
\hline $\begin{array}{l}\text { Targeted } \\
\text { NGS }\end{array}$ & $\begin{array}{l}\text { Plasma of patients with } \\
\text { advanced cancers } \\
\qquad(n=43)\end{array}$ & Exosome & $\begin{array}{l}\text { ExoLution Plus } \\
\text { Isolation kit }\end{array}$ & & $\begin{array}{l}\text { SNV of tumor } \\
\text { DNA (tissue) } \\
\text { and exoNA }\end{array}$ & 3 & [83] \\
\hline $\begin{array}{l}\text { Targeted } \\
\text { NGS }\end{array}$ & $\begin{array}{l}\text { Urine of patients with } \\
\text { urothelial bladder } \\
\text { carcinoma }(n=9)\end{array}$ & Exosome & ExoQuick-TC & $102-4909 \times$ & $\begin{array}{l}\text { SNV of tumor } \\
\text { DNA (tissue), } \\
\text { cfDNA, and } \\
\text { exoDNA }\end{array}$ & 9 & [70] \\
\hline $\begin{array}{l}\text { Targeted } \\
\text { NGS }\end{array}$ & $\begin{array}{l}\text { Plasma of PDAC } \\
\text { patients }\end{array}$ & Exosome & $\begin{array}{c}\text { Differential } \\
\text { ultracentrifugation } \\
\text { and cancer-specific } \\
\text { exosome capture }\end{array}$ & & $\begin{array}{l}\text { SNV of tumor } \\
\text { DNA (tissue) } \\
\text { and exoDNA }\end{array}$ & 275 & [136] \\
\hline $\begin{array}{l}\text { Targeted } \\
\text { NGS }\end{array}$ & $\begin{array}{l}\text { BALF of patients with } \\
\text { lung adenocarcinoma } \\
\qquad(n=20)\end{array}$ & $\begin{array}{c}\text { EV } \\
(207.0 \pm 48.3 \mathrm{~nm})\end{array}$ & $\begin{array}{c}\text { Differential } \\
\text { ultracentrifugation }\end{array}$ & $190-755 \times$ & $\begin{array}{l}\text { SNV of tumor } \\
\text { DNA (FFPE) } \\
\text { and EV DNA }\end{array}$ & 375 & [41] \\
\hline $\begin{array}{l}\text { Targeted } \\
\text { NGS }\end{array}$ & $\begin{array}{l}\text { Plasma of patients with } \\
\text { acute myeloid } \\
\text { leukemia }(n=4)\end{array}$ & $\begin{array}{c}\mathrm{EV} \\
(30-150 \mathrm{~nm})\end{array}$ & $\begin{array}{c}\text { Differential } \\
\text { ultracentrifugation }\end{array}$ & & $\begin{array}{l}\text { SNV of tumor } \\
\text { DNA and EV } \\
\text { DNA }\end{array}$ & 54 & [137] \\
\hline $\begin{array}{l}\text { Targeted } \\
\text { NGS }\end{array}$ & $\begin{array}{c}\text { Glioblastoma stem-like } \\
\text { cells }(n=8)\end{array}$ & EV & $\begin{array}{l}\text { Differential } \\
\text { ultracentrifugation } \\
\text { and filtration or } \\
\text { size exclusion } \\
\text { chromatography }\end{array}$ & & $\begin{array}{l}\text { SNV of tumor } \\
\text { DNA (tissue } \\
\text { and cell) and } \\
\text { exoDNA }\end{array}$ & 47 & [106] \\
\hline
\end{tabular}

NGS—next-generation sequencing; EV—extracellular vesicle; EV DNA-EV-derived DNA; WGS—whole-genome sequencing; CNVcopy number variation; exoDNA — exosome-derived DNA; SNV—single nucleotide variant; MSC — mesenchymal stromal cell; gDNA— genomic DNA; RPKM — reads per kilobase per million mapped reads; cfDNA—cell-free DNA; SNP—single nucleotide polymorphism; FFPE—formalin-fixed paraffin-embedded; WES—whole-exome sequencing; TMB — tumor mutation burden; PDAC—pancreatic ductal adenocarcinoma; BALF-bronchoalveolar lavage fluid.

\subsection{WGS and WES}

Cai J et al. [61], using WGS, observed a minimum of 16,434 gDNA fragments in EVs from the plasma of healthy humans. Kahlert's team [57] used exosome-derived DNA (exoDNA) from the serum of patients with pancreatic cancer and tumor DNA to map approximately $96 \%$ of the human genome using NGS. The properly paired percentage read $\sim 92 \%$ between tumor gDNA and exosome gDNA. Their analysis showed that the DNA found in exosomes isolated from the serum was uniform across all chromosomes [57]. In another study, WGS and comparative genomic hybridization analysis with the exoDNA of murine melanoma cells revealed the entire genome coverage of exoDNA without bias. In addition, no specific fragments were enriched or depleted in the exoDNA pool compared to gDNA [26]. Lee et al. [62] investigated the copy number variation (CNV) of human $\mathrm{H}$-ras-transformed rat intestinal epithelial cell EV-associated DNA. While the CNV research 
suggested an increase in the contribution of certain loci, they did not detect any genomic regions that would be selectively included in EVs. Indeed, over $90 \%$ of the cellular genome has been found in EVs [62]. A study with PC12 cells demonstrated that exoDNA covered $98 \%$ of the single nucleotide polymorphisms (SNPs) of the parent cell with WGS. They examined driver susceptibility gene mutations in exoDNA and found that the concordance rates of mutations in the exosome and tumor tissue DNA in patients with pheochromocytoma or paraganglioma were as high as 98-100\% [131]. Interestingly, WGS analysis using exoDNA from the plasma and ascites of patients with ovarian cancer identified gene mutations related to DNA repair, and revealed a similarity to the primary tumor in CNV only with ascite exosomes, but not plasma exosomes [72]. Several studies have demonstrated the potential of EV DNA for WGS, and have shown that EV DNA represents the whole genome of parental cells $[63,78,126,130]$. A study used exoDNA from the pleural effusion and plasma of patients with pancreatic biliary cancer for analyzing the CNV, SNV, gene fusions, and mutational signature using WGS and WES. In addition, exosome RNA (exoRNA) was used for transcriptome sequencing, and WES using exoDNA covered 95-99\% of the target regions. In this case, exoDNA was used for identifying mutant KRAS through WGS, WES, and transcriptome sequencing of pancreatic ductal adenocarcinoma [40]. Another study used large EV DNA isolated from the human prostate cancer cell PC3 to identify genomic rearrangements [35]. While CNV was not identified in normal blood samples, urinary cfDNA and exoDNA samples presented a similar pattern of CNV with tumor samples of urothelial bladder carcinoma [70]. In addition, fetal trisomy and single gene disease were identified by EV DNA in the maternal plasma. This study demonstrated that the GC content of the plasma EV DNA was 1.2 times higher than that of cfDNA. Moreover, mtDNA was detected in EVs using NGS, and the read percentage of mitochondrial EV DNA was, on an average, 2.2 times higher than that of cfDNA [132].

However, in a contradictory study, the EV DNA results were highly variable between patients with very limited overlapping regions, even when the EV DNA CNV profiles were compared to the CNV profile of formalin-fixed paraffin-embedded (FFPE)-derived DNA [134]. This difference could be due to the difference in DNA degradation during storage in FFPE tissue blocks $[138,139]$. In another study, only one case presented a lower sensitivity to tumor driver CNVs of breast cancer with EV DNA compared with ctDNA [133].

With neuroblastoma, a comparison of exoDNA and the corresponding tumor DNA using WES showed a higher overall number of somatic single nucleotide variants (SNVs). The difference in SNVs could arise from the different origins of exoDNA and tumor DNA, suggesting spatial genetic heterogeneity. In addition, the median tumor mutation burden (TMB) of exoDNA and tumor DNA was calculated. The higher TMB value observed in the exoDNA was probably because there were more exoDNA somatic SNVs than tumor DNA SNVs [135].

\subsection{Targeted NGS}

Many studies have tested the compatibility of EV DNA from different types of body fluids in various diseases for targeted NGS (Table 3). Evaluation of BALF EV DNA for the detection and quantification of mutations comparably identified lung adenocarcinomas with tissue DNA using targeted NGS. The DNA yield from BALF EV has been demonstrated to be 100 times higher than that from tissue samples. The median depth of coverage, median sequencing uniformity, and tumor purity were higher in the DNA from the tissue than in the BALF EV DNA. However, the estimated library size was not significantly different between the two samples, and the median DNA fragment length was slightly longer in the BALF EV DNA than in the tissue DNA. EGFR variants were the most commonly detected alterations, totaling 580 alterations in 175 genes. Furthermore, the overall mutation concordance between the two samples was high $(81 \%)$ for clinically significant mutations. In addition, the TMB of the BALF EV DNA was correlated with that of the tissue DNA [41]. 
A study performed on urine samples of patients with urothelial bladder carcinoma identified all 17 somatic mutations by analyzing cfDNA and exoDNA [70]. The compatibility was also demonstrated in a glioblastoma study comparing DNA from EVs, cells, and matching tissues; the study determined the variant allele frequencies (VAFs) to be similar [106].

Several studies have used plasma-derived EV DNA for NGS analyses. One study explored the plasma of patients with advanced cancer (colorectal cancer, melanoma, and NSCLC) to identify common hotspot mutations such as BRAF, EGFR, and KRAS to yield a very good overall sensitivity (95\%) with exoDNA and exoRNA compared with the standard testing of archival FFPE samples obtained from the tumor tissue. This high sensitivity of plasma exoDNA and exoRNA was similar to that of simultaneously tested plasma cfDNA with ddPCR and BEAMing (92\% and $97 \%$, respectively) [83].

For tumor exosome enrichment, using the plasma of pancreatic ductal adenocarcinoma (PDAC) patients, surface exosomal proteins were profiled to identify PDACspecific biomarkers using proteomic analysis, which led to an augmentation of mutant genomic equivalents that were suitable for subsequent NGS using a molecular barcoding approach [136]. In another plasma study of acute myeloid leukemia patients, EV DNA analyzed for leukemia-specific mutations using NGS mirrored the leukemia-specific mutations found in the gDNA obtained from the primary leukemia cells in most cases [137].

These studies demonstrated that EV DNA in patients with cancer can be a reliable source for targeted NGS for the identification of genetic alterations using diagnostic values with a high clinical feasibility and utility. For clinically reliable and suitable NGS analysis in the future, standardization and clinical verification are necessary.

\section{Challenges of Studying Extracellular Vesicles}

The heterogeneity of EVs and the presence of non-vesicular extracellular nanoparticles in fluid samples pose major obstacles to our understanding of the composition and functional properties of the secreted EV components [74,140]. In particular, in EV DNA research, the use of DNase to remove outer DNA and non-vesicular extracellular nanoparticles, as well as other appropriate separation methods, should be considered. EVs are most often categorized according to their size. Exosomes are the smallest vesicles with sizes ranging between 30 and $150 \mathrm{~nm}$, microvesicles typically range between 0.1 and $1 \mu \mathrm{m}$, and apoptotic bodies tend to have larger diameters of 50-5000 $\mathrm{nm}$ [29]. However, some microvesicles are smaller than $100 \mathrm{~nm}$, such as the recently identified arrestin domain-containing protein 1-mediated microvesicles, which are relatively on the smaller side, 40-100 nm [141,142]. Therefore, most isolation protocols are based on differences in size and buoyant density, such as gradient centrifugation, sediment centrifugation, ultracentrifugation, and size exclusion chromatography. Unfortunately, these approaches cannot differentiate the population of EVs with diameters ranging between 50 and $200 \mathrm{~nm}$, meaning that a pure population of exosomes, small apoptotic bodies, or microvesicles cannot be obtained using current methods. Consequently, most analyses are performed on EVs as a whole rather than on a pure exosomal population. Most studies use differential ultracentrifugation for the isolation of EVs, and some still prefer to use the term exosome. However, pure exosomes cannot be obtained by ultracentrifugation alone, and accordingly, it would be more appropriate to call them small EVs. To solve this problem, distinct surface markers can distinguish exosomes from other types of EVs [143].

Tetraspanins, CD63, CD81, and CD9 are most often used as specific markers for identifying exosomes; however, they are not a definite indication, as these proteins are abundantly expressed on the cell surface, including other types of EVs that are generated by budding from the plasma membrane [144,145]. Moreover, these markers of exosomes are not present in all cases; alternatively, some of the presumed components of exosomes were absent in the exosomes expressing these markers $[74,146,147]$. Therefore, a single marker cannot be used to identify all EVs within a population. Moreover, there is no 
method for isolating only a pure population of exosomes or microvesicles without traces of complex mixtures of EVs and other components from bio-fluids $[29,148]$.

A method capable of isolating pure exosomes or microvesicles needs to be developed. Although limitations to absolute differentiation between these types of EVs still exist, EVs isolated according to their size could be categorized as small or large EVs, or those isolated by the difference in their densities could be called either high-density or low-density EVs. Additional tests of certain protein markers and the identification of isolated EVs as markerpositive EVs, such as CD63 + EV, could be supplemented for supporting the categorization of EVs [31]. In summary, one should always clarify the method of EV isolation and define the characteristics before choosing the right nomenclature for isolated EVs.

\section{Discussion}

EVs are nanoparticles of 30-1000 $\mathrm{nm}$ in size, and are found almost everywhere in bodily fluids [115]. They are shed by various types of cells, but are most abundantly released by cancer cells and carry not only RNAs and proteins, but also DNA, including ssDNA and dsDNA, which originate from the gDNA and mtDNA of the parent cell [65]. Several recent studies have discovered that EVs hold dsDNA, including oncogenic mutant DNA studies performed with EVs derived from the plasma [95], pleural effusion [10], and BALF [98] of patients with cancer. These studies demonstrated that EV DNA presents a strong potential as a biomarker.

The application of NGS for clinical use has led to a new era of precision medicine powered by targeted therapies for cancer. Especially in lung cancer, various targeted therapies have been developed, ranging from EGFR-TKIs and BRAF, ALK, ROS, RET, MET, TRK1, and HER2 inhibitors [149], to more recent developments in KRAS inhibitors [150]. For immune therapy, assessing TMB using NGS has received attention as a biomarker [151]. In dealing with patient samples, separately identifying the biomarkers and diagnosis would consume time and resources; however, using NGS would save specimens and time $[152,153]$.

Unfortunately, in several cancers, small biopsy samples have become an obstacle for NGS. In reality, $30 \%$ of NSCLC patients face the problem of insufficient biopsy samples [154,155]. In addition to the small biopsy sample problem, other challenges faced in NGS are tumor heterogeneity [156] and artificial mutation of the fundamental FFPE tissues [157]. These shortcomings can be overcome through active clinical study of liquid NGS using plasma ctDNA $[158,159]$, which is clinically applicable as liquid NGS lung cancer panels have become commercially available [160]. The biggest advantage of using plasma ctDNA is its easy access; however, its fundamental limitation is its instability, with a half-life of approximately $2 \mathrm{~h}$ [161], which indicates that it does not live up to the high expectations. In fact, liquid biopsy currently plays a supporting role in cases where tissue biopsy fails or when the location of a tumor renders it difficult to remove a tissue sample. Larger size genomic dsDNA within the EVs of cancers, including human glioblastoma, prostate cancer, ovarian cancer, and lung cancer, has been verified, and it was found in the serum, plasma, pleural effusion, urine, ascites, and BALF of patients with cancer. These studies verified that WGS, WES, and targeted NGS analysis using EV DNA are all possible (Table 3). Furthermore, targeted NGS using BALF EV DNA showed that NGS was possible without the molecular barcoding approach, and the results were highly consistent with somatic mutations in the tumor DNA [41]. The liquid biopsy method is moving away from conventional PCR and expanding into NGS; with the use of EV DNA, it could expand much further. In the liquid biopsy field, NGS using EV DNA will become clinically useful in cancer diagnosis, companion diagnostics, and prognosis in the near future.

In addition, the methylation of EV DNA from the serum, plasma, saliva, and gastric juice has been studied (Table 1), and similarities between gDNA and EV DNA results have been verified, which suggests that the methylation analysis of EV DNA can serve as a useful biomarker for the detection of various diseases, especially cancer. However, as some results lead to doubts about using EV DNA for methylation analysis [71,107], the EV DNA 
source, sample collection, DNA extraction methods, and the disease appear to affect the detection of methylation.

Although most current research on EV DNA has focused on cancer, non-cancer studies also present the potential for exploration. In particular, BALF can be a useful source for identifying the biomarkers of diseases, including idiopathic pulmonary fibrosis (IPF) and chronic pulmonary obstructive disease (COPD) [162].

EV DNA is involved in intercellular communication, pathological communication of diseases, and genomic evolution. For example, in cancer, oncogenes of donor cells can be transformed into recipient cells by apoptotic bodies or the BCR/ABL hybrid gene in EVs, and then expressed on recipient cells. Horizontal plant DNA transfer in eukaryotic cells is also mediated by EVs. Transfer from bacteria to eukaryotes by OMV-derived DNA has been identified in the nuclear fraction of epithelial cells. Furthermore, cells that become resistant to therapy can transfer mtDNA by EVs to other non-resistant cells and exhibit therapy resistance both in vivo and in vitro (Table 2). This transfer of EV DNAs suggests the potential of EVs as carrier vesicles and for other therapeutic uses.

Currently, most research and clinical studies on EV DNA have focused on discovering biomarkers for liquid biopsy and its horizontal gene transferability. The biggest problem for the clinical application of EV DNA is the lack of basic research and characterization. To advance our understanding of EV DNA, we must establish the (1) intracellular processes involved in the loading mechanism of DNA onto extracellular vesicles, (2) specific cellular signals that load DNA onto EVs, (3) the mechanism of DNA transfer to recipient cells via EV, and (4) an EV-DNA-specific optimized isolation and analysis method for removing non-vesicular extracellular nanoparticles. Once a full understanding of EV DNA has been established, it would become valuable in many aspects as a clinical tool for diverse functions.

\section{Conclusions}

While there is a wealth of research examining EVs and EV DNAs, our understanding of the basics and definite characterization remains low. As the benefit of utilizing EV DNA for liquid biopsy is unquestionable, further research is required in establishing a reliable method of EV and EV DNA purification, exploring diseases other than cancer, and performing clinical research. In addition, verification of horizontal EV DNA transfer suggests the possibility of EVs as carrier vesicles and for other therapeutic uses, where a rigorous study of EV DNA loading and transfer mechanism is needed.

Author Contributions: Conceptualization, J.Y.H. and K.Y.L.; writing-original draft preparation, J.Y.H.; writing-review and editing, J.Y.H. and K.Y.L.; supervision, K.Y.L. Both authors have read and agreed to the published version of the manuscript.

Funding: This review was supported by Shin Poog Pharmaceutical Co., Ltd. (G2019000021).

Acknowledgments: We thank Min Kyo Jung for the electron microscopy images of the BALF EVs.

Conflicts of Interest: The authors declare no conflict of interest.

\section{References}

1. Gerber, D.E. Targeted therapies: A new generation of cancer treatments. Am. Fam. Physician 2008, 77, 311-319. [PubMed]

2. Farkona, S.; Diamandis, E.P.; Blasutig, I.M. Cancer immunotherapy: The beginning of the end of cancer? BMC Med. $2016,14,73$. [CrossRef] [PubMed]

3. Ginsburg, G.S.; Phillips, K.A. Precision Medicine: From Science to Value. Health Aff. 2018, 37, 694-701. [CrossRef]

4. Mattox, A.K.; Bettegowda, C.; Zhou, S.; Papadopoulos, N.; Kinzler, K.W.; Vogelstein, B. Applications of liquid biopsies for cancer. Sci. Transl. Med. 2019, 11, eaay1984. [CrossRef]

5. Crowley, E.; Di Nicolantonio, F.; Loupakis, F.; Bardelli, A. Liquid biopsy: Monitoring cancer-genetics in the blood. Nat. Rev. Clin. Oncol. 2013, 10, 472-484. [CrossRef] [PubMed]

6. Di Meo, A.; Bartlett, J.; Cheng, Y.; Pasic, M.D.; Yousef, G.M. Liquid biopsy: A step forward towards precision medicine in urologic malignancies. Mol. Cancer 2017, 16, 80. [CrossRef]

7. Aro, K.; Wei, F.; Wong, D.T.; Tu, M. Saliva liquid biopsy for point-of-care applications. Front. Public Health 2017, 5, 77. [CrossRef] 
8. $\quad$ Li, Y.S.; Jiang, B.Y.; Yang, J.J.; Zhang, X.C.; Zhang, Z.; Ye, J.Y.; Zhong, W.Z.; Tu, H.Y.; Chen, H.J.; Wang, Z.; et al. Unique genetic profiles from cerebrospinal fluid cell-free DNA in leptomeningeal metastases of EGFR-mutant non-small-cell lung cancer: A new medium of liquid biopsy. Ann. Oncol. 2018, 29, 945-952. [CrossRef]

9. Husain, H.; Nykin, D.; Bui, N.; Quan, D.; Gomez, G.; Woodward, B.; Venkatapathy, S.; Duttagupta, R.; Fung, E.; Lippman, S.M.; et al. Cell-Free DNA from Ascites and Pleural Effusions: Molecular Insights into Genomic Aberrations and Disease Biology. Mol. Cancer Ther. 2017, 16, 948-955. [CrossRef] [PubMed]

10. Lee, J.S.; Hur, J.Y.; Kim, I.A.; Kim, H.J.; Choi, C.M.; Lee, J.C.; Kim, W.S.; Lee, K.Y. Liquid biopsy using the supernatant of a pleural effusion for EGFR genotyping in pulmonary adenocarcinoma patients: A comparison between cell-free DNA and extracellular vesicle-derived DNA. BMC Cancer 2018, 18, 1236. [CrossRef]

11. Marrugo-Ramirez, J.; Mir, M.; Samitier, J. Blood-Based Cancer Biomarkers in Liquid Biopsy: A Promising Non-Invasive Alternative to Tissue Biopsy. Int. J. Mol. Sci. 2018, 19, 2877. [CrossRef] [PubMed]

12. Perdomo, S.; Avogbe, P.H.; Foll, M.; Abedi-Ardekani, B.; Facciolla, V.L.; Anantharaman, D.; Chopard, P.; Calvez-Kelm, F.L.; Vilensky, M.; Polesel, J.; et al. Circulating tumor DNA detection in head and neck cancer: Evaluation of two different detection approaches. Oncotarget 2017, 8, 72621-72632. [CrossRef] [PubMed]

13. Ou, Z.; Li, K.; Yang, T.; Dai, Y.; Chandra, M.; Ning, J.; Wang, Y.; Xu, R.; Gao, T.; Xie, Y.; et al. Detection of bladder cancer using urinary cell-free DNA and cellular DNA. Clin. Transl. Med. 2020, 9, 4. [CrossRef] [PubMed]

14. Ponti, G.; Manfredini, M.; Tomasi, A. Non-blood sources of cell-free DNA for cancer molecular profiling in clinical pathology and oncology. Crit. Rev. Oncol. Hematol. 2019, 141, 36-42. [CrossRef] [PubMed]

15. Hur, J.Y.; Kim, H.J.; Lee, J.S.; Choi, C.M.; Lee, J.C.; Jung, M.K.; Pack, C.G.; Lee, K.Y. Extracellular vesicle-derived DNA for performing EGFR genotyping of NSCLC patients. Mol. Cancer 2018, 17, 15. [CrossRef] [PubMed]

16. Bunda, S.; Zuccato, J.A.; Voisin, M.R.; Wang, J.Z.; Nassiri, F.; Patil, V.; Mansouri, S.; Zadeh, G. Liquid Biomarkers for Improved Diagnosis and Classification of CNS Tumors. Int. J. Mol. Sci. 2021, 22, 4548. [CrossRef]

17. Quandt, D.; Dieter Zucht, H.; Amann, A.; Wulf-Goldenberg, A.; Borrebaeck, C.; Cannarile, M.; Lambrechts, D.; Oberacher, H.; Garrett, J.; Nayak, T.; et al. Implementing liquid biopsies into clinical decision making for cancer immunotherapy. Oncotarget 2017, 8, 48507-48520. [CrossRef] [PubMed]

18. Jung, A.; Kirchner, T. Liquid Biopsy in Tumor Genetic Diagnosis. Dtsch. Aerzteblatt Int. 2018, 115, 169-174. [CrossRef] [PubMed]

19. Ilie, M.; Hofman, P. Pros: Can tissue biopsy be replaced by liquid biopsy? Transl. Lung Cancer Res. 2016, 5, 420-423. [CrossRef]

20. Russano, M.; Napolitano, A.; Ribelli, G.; Iuliani, M.; Simonetti, S.; Citarella, F.; Pantano, F.; Dell'Aquila, E.; Anesi, C.; Silvestris, N.; et al. Liquid biopsy and tumor heterogeneity in metastatic solid tumors: The potentiality of blood samples. J. Exp. Clin. Cancer Res. 2020, 39, 95. [CrossRef]

21. Kilgour, E.; Rothwell, D.G.; Brady, G.; Dive, C. Liquid Biopsy-Based Biomarkers of Treatment Response and Resistance. Cancer Cell 2020, 37, 485-495. [CrossRef]

22. Eguchi, A.; Kostallari, E.; Feldstein, A.E.; Shah, V.H. Extracellular vesicles, the liquid biopsy of the future. J. Hepatol. 2019, 70, 1292-1294. [CrossRef] [PubMed]

23. Zhou, B.; Xu, K.; Zheng, X.; Chen, T.; Wang, J.; Song, Y.; Shao, Y.; Zheng, S. Application of exosomes as liquid biopsy in clinical diagnosis. Signal Transduct. Target. Ther. 2020, 5, 144. [CrossRef]

24. Valencia, K.; Montuenga, L.M. Exosomes in Liquid Biopsy: The Nanometric World in the Pursuit of Precision Oncology. Cancers 2021, 13, 2147. [CrossRef] [PubMed]

25. Lu, L.; Risch, H.A. Exosomes: Potential for early detection in pancreatic cancer. Future Oncol. 2016, 12, 1081-1090. [CrossRef]

26. Thakur, B.K.; Zhang, H.; Becker, A.; Matei, I.; Huang, Y.; Costa-Silva, B.; Zheng, Y.; Hoshino, A.; Brazier, H.; Xiang, J.; et al. Double-stranded DNA in exosomes: A novel biomarker in cancer detection. Cell Res. 2014, 24, 766-769. [CrossRef]

27. Cai, J.; Wu, G.; Jose, P.A.; Zeng, C. Functional transferred DNA within extracellular vesicles. Exp. Cell Res. 2016, 349, 179-183. [CrossRef] [PubMed]

28. Fujita, Y.; Yoshioka, Y.; Ochiya, T. Extracellular vesicle transfer of cancer pathogenic components. Cancer Sci. 2016, 107, 385-390. [CrossRef]

29. Doyle, L.M.; Wang, M.Z. Overview of Extracellular Vesicles, Their Origin, Composition, Purpose, and Methods for Exosome Isolation and Analysis. Cells 2019, 8, 727. [CrossRef]

30. El Andaloussi, S.; Mager, I.; Breakefield, X.O.; Wood, M.J. Extracellular vesicles: Biology and emerging therapeutic opportunities. Nat. Rev. Drug Discov. 2013, 12, 347-357. [CrossRef]

31. Thery, C.; Witwer, K.W.; Aikawa, E.; Alcaraz, M.J.; Anderson, J.D.; Andriantsitohaina, R.; Antoniou, A.; Arab, T.; Archer, F.; Atkin-Smith, G.K.; et al. Minimal information for studies of extracellular vesicles 2018 (MISEV2018): A position statement of the International Society for Extracellular Vesicles and update of the MISEV2014 guidelines. J. Extracell. Vesicles 2018, 7, 1535750. [CrossRef] [PubMed]

32. Whiteside, T.L. Tumor-Derived Exosomes and Their Role in Cancer Progression. Adv. Clin. Chem. 2016, 74, 103-141. [PubMed]

33. Taylor, D.D.; Gercel-Taylor, C. MicroRNA signatures of tumor-derived exosomes as diagnostic biomarkers of ovarian cancer. Gynecol. Oncol. 2008, 110, 13-21. [CrossRef] [PubMed]

34. Rosell, R.; Wei, J.; Taron, M. Circulating MicroRNA Signatures of Tumor-Derived Exosomes for Early Diagnosis of Non-Small-Cell Lung Cancer. Clin. Lung Cancer 2009, 10, 8-9. [CrossRef] [PubMed] 
35. Vagner, T.; Spinelli, C.; Minciacchi, V.R.; Balaj, L.; Zandian, M.; Conley, A.; Zijlstra, A.; Freeman, M.R.; Demichelis, F.; De, S.; et al. Large extracellular vesicles carry most of the tumour DNA circulating in prostate cancer patient plasma. J. Extracell. Vesicles 2018, 7, 1505403. [CrossRef]

36. Kahlert, C. Liquid Biopsy: Is There an Advantage to Analyzing Circulating Exosomal DNA Compared to cfDNA or Are They the Same? Cancer Res. 2019, 79, 2462-2465. [CrossRef] [PubMed]

37. Mouliere, F.; Chandrananda, D.; Piskorz, A.M.; Moore, E.K.; Morris, J.; Ahlborn, L.B.; Mair, R.; Goranova, T.; Marass, F.; Heider, K.; et al. Enhanced detection of circulating tumor DNA by fragment size analysis. Sci. Transl. Med. 2018, 10, eaat4921. [CrossRef] [PubMed]

38. Gorgannezhad, L.; Umer, M.; Islam, M.N.; Nguyen, N.T.; Shiddiky, M.J.A. Circulating tumor DNA and liquid biopsy: Opportunities, challenges, and recent advances in detection technologies. Lab Chip 2018, 18, 1174-1196. [CrossRef]

39. Jin, Y.; Chen, K.; Wang, Z.; Wang, Y.; Liu, J.; Lin, L.; Shao, Y.; Gao, L.; Yin, H.; Cui, C.; et al. DNA in serum extracellular vesicles is stable under different storage conditions. BMC Cancer 2016, 16, 753. [CrossRef]

40. San Lucas, F.A.; Allenson, K.; Bernard, V.; Castillo, J.; Kim, D.U.; Ellis, K.; Ehli, E.A.; Davies, G.E.; Petersen, J.L.; Li, D.; et al. Minimally invasive genomic and transcriptomic profiling of visceral cancers by next-generation sequencing of circulating exosomes. Ann. Oncol. 2016, 27, 635-641. [CrossRef]

41. Lee, S.E.; Park, H.Y.; Hur, J.Y.; Kim, H.J.; Kim, I.A.; Kim, W.S.; Lee, K.Y. Genomic profiling of extracellular vesicle-derived DNA from bronchoalveolar lavage fluid of patients with lung adenocarcinoma. Transl. Lung Cancer Res. 2021, 10, 104-116. [CrossRef] [PubMed]

42. Dalton, A.J. Microvesicles and vesicles of multivesicular bodies versus "virus-like" particles. J. Natl. Cancer Inst. 1975, 54, 1137-1148. [CrossRef]

43. Chargaff, E.; West, R. The biological significance of the thromboplastic protein of blood. J. Biol. Chem. 1946, 166, $189-197$. [CrossRef]

44. Wolf, P. The nature and significance of platelet products in human plasma. Br. J. Haematol. 1967, 13, 269-288. [CrossRef] [PubMed]

45. Bonucci, E. Fine structure and histochemistry of "calcifying globules" in epiphyseal cartilage. Z. Zellforsch. Mikrosk. Anat. 1970, 103, 192-217. [CrossRef]

46. Dvorak, H.F.; Quay, S.C.; Orenstein, N.S.; Dvorak, A.M.; Hahn, P.; Bitzer, A.M.; Carvalho, A.C. Tumor shedding and coagulation. Science 1981, 212, 923-924. [CrossRef] [PubMed]

47. Pan, B.T.; Johnstone, R.M. Fate of the transferrin receptor during maturation of sheep reticulocytes in vitro: Selective externalization of the receptor. Cell 1983, 33, 967-978. [CrossRef]

48. Johnstone, R.M.; Adam, M.; Hammond, J.R.; Orr, L.; Turbide, C. Vesicle formation during reticulocyte maturation. Association of plasma membrane activities with released vesicles (exosomes). J. Biol. Chem. 1987, 262, 9412-9420. [CrossRef]

49. Ceccarini, M.; Guidoni, L.; Luciani, A.M.; Mariutti, G.; Rosi, A.; Viti, V. Biochemical and NMR studies on structure and release conditions of RNA-containing vesicles shed by human colon adenocarcinoma cells. Int. J. Cancer 1989, 44, 714-721. [CrossRef]

50. Raposo, G.; Nijman, H.W.; Stoorvogel, W.; Liejendekker, R.; Harding, C.V.; Melief, C.J.; Geuze, H.J. B lymphocytes secrete antigen-presenting vesicles. J. Exp. Med. 1996, 183, 1161-1172. [CrossRef]

51. Baj-Krzyworzeka, M.; Szatanek, R.; Weglarczyk, K.; Baran, J.; Urbanowicz, B.; Branski, P.; Ratajczak, M.Z.; Zembala, M. Tumourderived microvesicles carry several surface determinants and mRNA of tumour cells and transfer some of these determinants to monocytes. Cancer Immunol. Immunother. 2006, 55, 808-818. [CrossRef]

52. Valadi, H.; Ekstrom, K.; Bossios, A.; Sjostrand, M.; Lee, J.J.; Lotvall, J.O. Exosome-mediated transfer of mRNAs and microRNAs is a novel mechanism of genetic exchange between cells. Nat. Cell Biol. 2007, 9, 654-659. [CrossRef]

53. Kahn, M.; Concino, M.; Gromkova, R.; Goodgal, S. DNA binding activity of vesicles produced by competence deficient mutants of Haemophilus. Biochem. Biophys. Res. Commun. 1979, 87, 764-772. [CrossRef]

54. Kahn, M.E.; Maul, G.; Goodgal, S.H. Possible mechanism for donor DNA binding and transport in Haemophilus. Proc. Natl. Acad. Sci. USA 1982, 79, 6370-6374. [CrossRef] [PubMed]

55. Bomberger, J.M.; Maceachran, D.P.; Coutermarsh, B.A.; Ye, S.; O’Toole, G.A.; Stanton, B.A. Long-distance delivery of bacterial virulence factors by Pseudomonas aeruginosa outer membrane vesicles. PLoS Pathog. 2009, 5, e1000382. [CrossRef]

56. Bitto, N.J.; Chapman, R.; Pidot, S.; Costin, A.; Lo, C.; Choi, J.; D'Cruze, T.; Reynolds, E.C.; Dashper, S.G.; Turnbull, L.; et al. Bacterial membrane vesicles transport their DNA cargo into host cells. Sci. Rep. 2017, 7, 7072. [CrossRef] [PubMed]

57. Kahlert, C.; Melo, S.A.; Protopopov, A.; Tang, J.; Seth, S.; Koch, M.; Zhang, J.; Weitz, J.; Chin, L.; Futreal, A.; et al. Identification of double-stranded genomic DNA spanning all chromosomes with mutated KRAS and p53 DNA in the serum exosomes of patients with pancreatic cancer. J. Biol. Chem. 2014, 289, 3869-3875. [CrossRef] [PubMed]

58. Emelyanov, A.; Shtam, T.; Kamyshinsky, R.; Garaeva, L.; Verlov, N.; Miliukhina, I.; Kudrevatykh, A.; Gavrilov, G.; Zabrodskaya, Y.; Pchelina, S.; et al. Cryo-electron microscopy of extracellular vesicles from cerebrospinal fluid. PLoS ONE 2020, 15, e0227949. [CrossRef]

59. Konoshenko, M.; Sagaradze, G.; Orlova, E.; Shtam, T.; Proskura, K.; Kamyshinsky, R.; Yunusova, N.; Alexandrova, A.; Efimenko, A.; Tamkovich, S. Total Blood Exosomes in Breast Cancer: Potential Role in Crucial Steps of Tumorigenesis. Int. J. Mol. Sci. 2020, 21, 7341. [CrossRef]

60. Balaj, L.; Lessard, R.; Dai, L.; Cho, Y.J.; Pomeroy, S.L.; Breakefield, X.O.; Skog, J. Tumour microvesicles contain retrotransposon elements and amplified oncogene sequences. Nat. Commun. 2011, 2, 180. [CrossRef] 
61. Cai, J.; Han, Y.; Ren, H.; Chen, C.; He, D.; Zhou, L.; Eisner, G.M.; Asico, L.D.; Jose, P.A.; Zeng, C. Extracellular vesicle-mediated transfer of donor genomic DNA to recipient cells is a novel mechanism for genetic influence between cells. J. Mol. Cell Biol. 2013, 5, 227-238. [CrossRef]

62. Lee, T.H.; Chennakrishnaiah, S.; Audemard, E.; Montermini, L.; Meehan, B.; Rak, J. Oncogenic ras-driven cancer cell vesiculation leads to emission of double-stranded DNA capable of interacting with target cells. Biochem. Biophys. Res. Commun. 2014, 451, 295-301. [CrossRef]

63. Lazaro-Ibanez, E.; Lasser, C.; Shelke, G.V.; Crescitelli, R.; Jang, S.C.; Cvjetkovic, A.; Garcia-Rodriguez, A.; Lotvall, J. DNA analysis of low- and high-density fractions defines heterogeneous subpopulations of small extracellular vesicles based on their DNA cargo and topology. J. Extracell. Vesicles 2019, 8, 1656993. [CrossRef]

64. Malkin, E.Z.; Bratman, S.V. Bioactive DNA from extracellular vesicles and particles. Cell Death Dis. 2020, 11, 584. [CrossRef] [PubMed]

65. Elzanowska, J.; Semira, C.; Costa-Silva, B. DNA in extracellular vesicles: Biological and clinical aspects. Mol. Oncol. 2020, 15, 1701. [CrossRef] [PubMed]

66. Erdmann, S.; Tschitschko, B.; Zhong, L.; Raftery, M.J.; Cavicchioli, R. A plasmid from an Antarctic haloarchaeon uses specialized membrane vesicles to disseminate and infect plasmid-free cells. Nat. Microbiol. 2017, 2, 1446-1455. [CrossRef]

67. Grull, M.P.; Mulligan, M.E.; Lang, A.S. Small extracellular particles with big potential for horizontal gene transfer: Membrane vesicles and gene transfer agents. FEMS Microbiol. Lett. 2018, 365, fny192. [CrossRef]

68. Lazaro-Ibanez, E.; Sanz-Garcia, A.; Visakorpi, T.; Escobedo-Lucea, C.; Siljander, P.; Ayuso-Sacido, A.; Yliperttula, M. Different gDNA content in the subpopulations of prostate cancer extracellular vesicles: Apoptotic bodies, microvesicles, and exosomes. Prostate 2014, 74, 1379-1390. [CrossRef] [PubMed]

69. Kawamura, Y.; Yamamoto, Y.; Sato, T.A.; Ochiya, T. Extracellular vesicles as trans-genomic agents: Emerging roles in disease and evolution. Cancer Sci. 2017, 108, 824-830. [CrossRef]

70. Lee, D.H.; Yoon, H.; Park, S.; Kim, J.S.; Ahn, Y.H.; Kwon, K.; Lee, D.; Kim, K.H. Urinary Exosomal and cell-free DNA Detects Somatic Mutation and Copy Number Alteration in Urothelial Carcinoma of Bladder. Sci. Rep. 2018, 8, 14707. [CrossRef] [PubMed]

71. Han, P.; Lai, A.; Salomon, C.; Ivanovski, S. Detection of Salivary Small Extracellular Vesicles Associated Inflammatory Cytokines Gene Methylation in Gingivitis. Int. J. Mol. Sci. 2020, 21, 5273. [CrossRef]

72. Yokoi, A.; Villar-Prados, A.; Oliphint, P.A.; Zhang, J.; Song, X.; De Hoff, P.; Morey, R.; Liu, J.; Roszik, J.; Clise-Dwyer, K.; et al. Mechanisms of nuclear content loading to exosomes. Sci. Adv. 2019, 5, eaax8849. [CrossRef]

73. Yoshida, Y.; Yamamoto, H.; Morita, R.; Oikawa, R.; Matsuo, Y.; Maehata, T.; Nosho, K.; Watanabe, Y.; Yasuda, H.; Itoh, F. Detection of DNA methylation of gastric juice-derived exosomes in gastric cancer. Integr. Mol. Med. 2014, 1, 17.

74. Jeppesen, D.K.; Fenix, A.M.; Franklin, J.L.; Higginbotham, J.N.; Zhang, Q.; Zimmerman, L.J.; Liebler, D.C.; Ping, J.; Liu, Q.; Evans, R.; et al. Reassessment of Exosome Composition. Cell 2019, 177, 428-445.e18. [CrossRef]

75. Shen, M.; Di, K.; He, H.; Xia, Y.; Xie, H.; Huang, R.; Liu, C.; Yang, M.; Zheng, S.; He, N.; et al. Progress in exosome associated tumor markers and their detection methods. Mol. Biomed. 2020, 1, 3. [CrossRef]

76. Cutter, A.R.; Hayes, J.J. A brief review of nucleosome structure. FEBS Lett. 2015, 589 Pt A, 2914-2922. [CrossRef]

77. Torralba, D.; Baixauli, F.; Villarroya-Beltri, C.; Fernandez-Delgado, I.; Latorre-Pellicer, A.; Acin-Perez, R.; Martin-Cofreces, N.B.; Jaso-Tamame, A.L.; Iborra, S.; Jorge, I.; et al. Priming of dendritic cells by DNA-containing extracellular vesicles from activated T cells through antigen-driven contacts. Nat. Commun. 2018, 9, 2658. [CrossRef] [PubMed]

78. Takahashi, A.; Okada, R.; Nagao, K.; Kawamata, Y.; Hanyu, A.; Yoshimoto, S.; Takasugi, M.; Watanabe, S.; Kanemaki, M.T.; Obuse, C.; et al. Exosomes maintain cellular homeostasis by excreting harmful DNA from cells. Nat. Commun. 2017, 8, 15287. [CrossRef] [PubMed]

79. Amintas, S.; Vendrely, V.; Dupin, C.; Buscail, L.; Laurent, C.; Bournet, B.; Merlio, J.P.; Bedel, A.; Moreau-Gaudry, F.; Boutin, J.; et al Next-Generation Cancer Biomarkers: Extracellular Vesicle DNA as a Circulating Surrogate of Tumor DNA. Front. Cell Dev. Biol. 2020, 8, 622048. [CrossRef]

80. Kim, I.A.; Hur, J.Y.; Kim, H.J.; Lee, S.E.; Kim, W.S.; Lee, K.Y. Liquid biopsy using extracellular vesicle-derived DNA in lung adenocarcinoma. J. Pathol. Transl. Med. 2020, 54, 453-461. [CrossRef]

81. Chang, X.; Fang, L.; Bai, J.; Wang, Z. Characteristics and Changes of DNA in Extracellular Vesicles. DNA Cell Biol. 2020, 39, 1486-1493. [CrossRef] [PubMed]

82. Kim, Y.; Shin, S.; Kim, B.; Lee, K.A. Selecting short length nucleic acids localized in exosomes improves plasma EGFR mutation detection in NSCLC patients. Cancer Cell Int. 2019, 19, 251. [CrossRef]

83. Mohrmann, L.; Huang, H.J.; Hong, D.S.; Tsimberidou, A.M.; Fu, S.; Piha-Paul, S.A.; Subbiah, V.; Karp, D.D.; Naing, A.; Krug, A.; et al. Liquid Biopsies Using Plasma Exosomal Nucleic Acids and Plasma Cell-Free DNA Compared with Clinical Outcomes of Patients with Advanced Cancers. Clin. Cancer Res. 2018, 24, 181-188. [CrossRef]

84. Castellanos-Rizaldos, E.; Grimm, D.G.; Tadigotla, V.; Hurley, J.; Healy, J.; Neal, P.L.; Sher, M.; Venkatesan, R.; Karlovich, C.; Raponi, M.; et al. Exosome-Based Detection of EGFR T790M in Plasma from Non-Small Cell Lung Cancer Patients. Clin. Cancer Res. 2018, 24, 2944-2950. [CrossRef] [PubMed]

85. Kim, Y.; Shin, S.; Lee, K.A. Exosome-based detection of EGFR T790M in plasma and pleural fluid of prospectively enrolled non-small cell lung cancer patients after first-line tyrosine kinase inhibitor therapy. Cancer Cell Int. 2021, 21, 50. [CrossRef] [PubMed] 
86. Garcia-Romero, N.; Madurga, R.; Rackov, G.; Palacin-Aliana, I.; Nunez-Torres, R.; Asensi-Puig, A.; Carrion-Navarro, J.; EstebanRubio, S.; Peinado, H.; Gonzalez-Neira, A.; et al. Polyethylene glycol improves current methods for circulating extracellular vesicle-derived DNA isolation. J. Transl. Med. 2019, 17, 75. [CrossRef]

87. Kamyabi, N.; Abbasgholizadeh, R.; Maitra, A.; Ardekani, A.; Biswal, S.L.; Grande-Allen, K.J. Isolation and mutational assessment of pancreatic cancer extracellular vesicles using a microfluidic platform. Biomed. Microdevices 2020, 22, 23. [CrossRef] [PubMed]

88. Akuma, P.; Okagu, O.D.; Udenigwe, C.C. Naturally Occurring Exosome Vesicles as Potential Delivery Vehicle for Bioactive Compounds. Front. Sustain. Food Syst. 2019, 3, 23. [CrossRef]

89. Jeyaram, A.; Jay, S.M. Preservation and Storage Stability of Extracellular Vesicles for Therapeutic Applications. AAPS J. 2017, 20, 1. [CrossRef]

90. Osteikoetxea, X.; Sodar, B.; Nemeth, A.; Szabo-Taylor, K.; Paloczi, K.; Vukman, K.V.; Tamasi, V.; Balogh, A.; Kittel, A.; Pallinger, E.; et al. Differential detergent sensitivity of extracellular vesicle subpopulations. Org. Biomol. Chem. 2015, 13, 9775-9782. [CrossRef]

91. Thery, C.; Amigorena, S.; Raposo, G.; Clayton, A. Isolation and characterization of exosomes from cell culture supernatants and biological fluids. Curr. Protoc. Cell Biol. 2006, 30, 3-22. [CrossRef]

92. Munagala, R.; Aqil, F.; Jeyabalan, J.; Gupta, R.C. Bovine milk-derived exosomes for drug delivery. Cancer Lett. 2016, 371, 48-61. [CrossRef]

93. Kalra, H.; Adda, C.G.; Liem, M.; Ang, C.S.; Mechler, A.; Simpson, R.J.; Hulett, M.D.; Mathivanan, S. Comparative proteomics evaluation of plasma exosome isolation techniques and assessment of the stability of exosomes in normal human blood plasma. Proteomics 2013, 13, 3354-3364. [CrossRef] [PubMed]

94. Kumeda, N.; Ogawa, Y.; Akimoto, Y.; Kawakami, H.; Tsujimoto, M.; Yanoshita, R. Characterization of Membrane Integrity and Morphological Stability of Human Salivary Exosomes. Biol. Pharm. Bull. 2017, 40, 1183-1191. [CrossRef] [PubMed]

95. Allenson, K.; Castillo, J.; San Lucas, F.A.; Scelo, G.; Kim, D.U.; Bernard, V.; Davis, G.; Kumar, T.; Katz, M.; Overman, M.J.; et al. High prevalence of mutant KRAS in circulating exosome-derived DNA from early-stage pancreatic cancer patients. Ann. Oncol. 2017, 28, 741-747. [CrossRef]

96. Wan, Y.; Liu, B.; Lei, H.; Zhang, B.; Wang, Y.; Huang, H.; Chen, S.; Feng, Y.; Zhu, L.; Gu, Y.; et al. Nanoscale extracellular vesicle-derived DNA is superior to circulating cell-free DNA for mutation detection in early-stage non-small-cell lung cancer. Ann. Oncol. 2018, 29, 2379-2383. [CrossRef]

97. Park, J.; Lee, C.; Eom, J.S.; Kim, M.H.; Cho, Y.K. Detection of EGFR Mutations Using Bronchial Washing-Derived Extracellular Vesicles in Patients with Non-Small-Cell Lung Carcinoma. Cancers 2020, 12, 2822. [CrossRef]

98. Hur, J.Y.; Lee, J.S.; Kim, I.A.; Kim, H.J.; Kim, W.S.; Lee, K.Y. Extracellular vesicle-based EGFR genotyping in bronchoalveolar lavage fluid from treatment-naive non-small cell lung cancer patients. Transl. Lung Cancer Res. 2019, 8, 1051-1060. [CrossRef]

99. Kulis, M.; Esteller, M. DNA methylation and cancer. Adv. Genet. 2010, 70, 27-56. [PubMed]

100. Locke, W.J.; Guanzon, D.; Ma, C.; Liew, Y.J.; Duesing, K.R.; Fung, K.Y.C.; Ross, J.P. DNA Methylation Cancer Biomarkers: Translation to the Clinic. Front. Genet. 2019, 10, 1150. [CrossRef]

101. Jin, Z.; Liu, Y. DNA methylation in human diseases. Genes Dis. 2018, 5, 1-8. [CrossRef]

102. Yamamoto, H.; Watanabe, Y.; Oikawa, R.; Morita, R.; Yoshida, Y.; Maehata, T.; Yasuda, H.; Itoh, F. BARHL2 Methylation Using Gastric Wash DNA or Gastric Juice Exosomal DNA is a Useful Marker For Early Detection of Gastric Cancer in an H. pylori-Independent Manner. Clin. Transl. Gastroenterol. 2016, 7, e184. [CrossRef]

103. Sina, A.A.; Lin, T.Y.; Vaidyanathan, R.; Wang, Z.; Dey, S.; Wang, J.; Behren, A.; Wuethrich, A.; Carrascosa, L.G.; Trau, M. Methylation dependent gold adsorption behaviour identifies cancer derived extracellular vesicular DNA. Nanoscale Horiz. 2020, 5, 1317-1323. [CrossRef]

104. Zavridou, M.; Strati, A.; Bournakis, E.; Smilkou, S.; Tserpeli, V.; Lianidou, E. Prognostic Significance of Gene Expression and DNA Methylation Markers in Circulating Tumor Cells and Paired Plasma Derived Exosomes in Metastatic Castration Resistant Prostate Cancer. Cancers 2021, 13, 780. [CrossRef]

105. Baris, I.C.; Hacioglu, S.; Turk, N.S.; Cetin, G.O.; Zencir, S.; Bagci, G.; Caner, V. Expression and DNA methylation profiles of EZH2-target genes in plasma exosomes and matched primary tumor tissues of the patients with diffuse large B-cell lymphoma. Clin. Transl. Oncol. 2021, 23, 1152-1166. [CrossRef]

106. Maire, C.L.; Fuh, M.M.; Kaulich, K.; Fita, K.D.; Stevic, I.; Heiland, D.H.; Welsh, J.A.; Jones, J.C.; Gorgens, A.; Ricklefs, T.; et al. Genome-wide methylation profiling of glioblastoma cell-derived extracellular vesicle DNA allows tumor classification. Neuro Oncol. 2021, 23, 1087. [CrossRef]

107. Han, P.; Bartold, P.M.; Salomon, C.; Ivanovski, S. Salivary Outer Membrane Vesicles and DNA Methylation of Small Extracellular Vesicles as Biomarkers for Periodontal Status: A Pilot Study. Int. J. Mol. Sci. 2021, 22, 2423. [CrossRef]

108. Reis-Sobreiro, M.; Chen, J.F.; Novitskaya, T.; You, S.; Morley, S.; Steadman, K.; Gill, N.K.; Eskaros, A.; Rotinen, M.; Chu, C.Y.; et al. Emerin Deregulation Links Nuclear Shape Instability to Metastatic Potential. Cancer Res. 2018, 78, 6086-6097. [CrossRef] [PubMed]

109. Yu, X.; Harris, S.L.; Levine, A.J. The regulation of exosome secretion: A novel function of the p53 protein. Cancer Res. 2006, 66, 4795-4801. [CrossRef] [PubMed]

110. Bianco, F.; Perrotta, C.; Novellino, L.; Francolini, M.; Riganti, L.; Menna, E.; Saglietti, L.; Schuchman, E.H.; Furlan, R.; Clementi, E.; et al. Acid sphingomyelinase activity triggers microparticle release from glial cells. EMBO J. 2009, 28, 1043-1054. [CrossRef] [PubMed] 
111. Jorch, S.K.; Kubes, P. An emerging role for neutrophil extracellular traps in noninfectious disease. Nat. Med. $2017,23,279-287$. [CrossRef]

112. Nolte-'t Hoen, E.; Cremer, T.; Gallo, R.C.; Margolis, L.B. Extracellular vesicles and viruses: Are they close relatives? Proc. Natl. Acad. Sci. USA 2016, 113, 9155-9161. [CrossRef] [PubMed]

113. Bello-Morales, R.; Lopez-Guerrero, J.A. Extracellular Vesicles in Herpes Viral Spread and Immune Evasion. Front. Microbiol. 2018, 9, 2572. [CrossRef] [PubMed]

114. Maacha, S.; Bhat, A.A.; Jimenez, L.; Raza, A.; Haris, M.; Uddin, S.; Grivel, J.C. Extracellular vesicles-mediated intercellular communication: Roles in the tumor microenvironment and anti-cancer drug resistance. Mol. Cancer 2019, 18, 55. [CrossRef] [PubMed]

115. Yanez-Mo, M.; Siljander, P.R.; Andreu, Z.; Zavec, A.B.; Borras, F.E.; Buzas, E.I.; Buzas, K.; Casal, E.; Cappello, F.; Carvalho, J.; et al. Biological properties of extracellular vesicles and their physiological functions. J. Extracell. Vesicles 2015, 4, 27066. [CrossRef] [PubMed]

116. Xu, R.; Greening, D.W.; Zhu, H.J.; Takahashi, N.; Simpson, R.J. Extracellular vesicle isolation and characterization: Toward clinical application. J. Clin. Investig. 2016, 126, 1152-1162. [CrossRef]

117. Kooijmans, S.A.A.; Stremersch, S.; Braeckmans, K.; de Smedt, S.C.; Hendrix, A.; Wood, M.J.A.; Schiffelers, R.M.; Raemdonck, K.; Vader, P. Electroporation-induced siRNA precipitation obscures the efficiency of siRNA loading into extracellular vesicles. $J$. Control. Release 2013, 172, 229-238. [CrossRef]

118. Lamichhane, T.N.; Raiker, R.S.; Jay, S.M. Exogenous DNA Loading into Extracellular Vesicles via Electroporation is Size-Dependent and Enables Limited Gene Delivery. Mol. Pharm. 2015, 12, 3650-3657. [CrossRef]

119. Kanada, M.; Bachmann, M.H.; Hardy, J.W.; Frimannson, D.O.; Bronsart, L.; Wang, A.; Sylvester, M.D.; Schmidt, T.L.; Kaspar, R.L.; Butte, M.J.; et al. Differential fates of biomolecules delivered to target cells via extracellular vesicles. Proc. Natl. Acad. Sci. USA 2015, 112, E1433-E1442. [CrossRef]

120. Ciardiello, C.; Cavallini, L.; Spinelli, C.; Yang, J.; Reis-Sobreiro, M.; de Candia, P.; Minciacchi, V.R.; Di Vizio, D. Focus on Extracellular Vesicles: New Frontiers of Cell-to-Cell Communication in Cancer. Int. J. Mol. Sci. 2016, 17, 175. [CrossRef]

121. Del Conde, I.; Shrimpton, C.N.; Thiagarajan, P.; Lopez, J.A. Tissue-factor-bearing microvesicles arise from lipid rafts and fuse with activated platelets to initiate coagulation. Blood 2005, 106, 1604-1611. [CrossRef]

122. Mulcahy, L.A.; Pink, R.C.; Carter, D.R. Routes and mechanisms of extracellular vesicle uptake. J. Extracell. Vesicles 2014, 3. [CrossRef]

123. Bergsmedh, A.; Szeles, A.; Henriksson, M.; Bratt, A.; Folkman, M.J.; Spetz, A.L.; Holmgren, L. Horizontal transfer of oncogenes by uptake of apoptotic bodies. Proc. Natl. Acad. Sci. USA 2001, 98, 6407-6411. [CrossRef]

124. Holmgren, L.; Szeles, A.; Rajnavolgyi, E.; Folkman, J.; Klein, G.; Ernberg, I.; Falk, K.I. Horizontal transfer of DNA by the uptake of apoptotic bodies. Blood 1999, 93, 3956-3963. [CrossRef]

125. Waldenstrom, A.; Genneback, N.; Hellman, U.; Ronquist, G. Cardiomyocyte microvesicles contain DNA/RNA and convey biological messages to target cells. PLoS ONE 2012, 7, e34653. [CrossRef]

126. Fischer, S.; Cornils, K.; Speiseder, T.; Badbaran, A.; Reimer, R.; Indenbirken, D.; Grundhoff, A.; Brunswig-Spickenheier, B.; Alawi, M.; Lange, C. Indication of Horizontal DNA Gene Transfer by Extracellular Vesicles. PLoS ONE 2016, 11, e0163665. [CrossRef] [PubMed]

127. Sansone, P.; Savini, C.; Kurelac, I.; Chang, Q.; Amato, L.B.; Strillacci, A.; Stepanova, A.; Iommarini, L.; Mastroleo, C.; Daly, L.; et al. Packaging and transfer of mitochondrial DNA via exosomes regulate escape from dormancy in hormonal therapy-resistant breast cancer. Proc. Natl. Acad. Sci. USA 2017, 114, E9066-E9075. [CrossRef] [PubMed]

128. Ono, R.; Yasuhiko, Y.; Aisaki, K.I.; Kitajima, S.; Kanno, J.; Hirabayashi, Y. Exosome-mediated horizontal gene transfer occurs in double-strand break repair during genome editing. Commun. Biol. 2019, 2, 57. [CrossRef] [PubMed]

129. Minciacchi, V.R.; Freeman, M.R.; Di Vizio, D. Extracellular vesicles in cancer: Exosomes, microvesicles and the emerging role of large oncosomes. Semin. Cell Dev. Biol. 2015, 40, 41-51. [CrossRef] [PubMed]

130. Sisquella, X.; Ofir-Birin, Y.; Pimentel, M.A.; Cheng, L.; Abou Karam, P.; Sampaio, N.G.; Penington, J.S.; Connolly, D.; Giladi, T.; Scicluna, B.J.; et al. Malaria parasite DNA-harbouring vesicles activate cytosolic immune sensors. Nat. Commun. 2017, 8, 1985. [CrossRef]

131. Wang, L.; Li, Y.; Guan, X.; Zhao, J.; Shen, L.; Liu, J. Exosomal double-stranded DNA as a biomarker for the diagnosis and preoperative assessment of pheochromocytoma and paraganglioma. Mol. Cancer 2018, 17, 128. [CrossRef]

132. Zhang, W.; Lu, S.; Pu, D.; Zhang, H.; Yang, L.; Zeng, P.; Su, F.; Chen, Z.; Guo, M.; Gu, Y.; et al. Detection of fetal trisomy and single gene disease by massively parallel sequencing of extracellular vesicle DNA in maternal plasma: A proof-of-concept validation. BMC Med. Genom. 2019, 12, 151. [CrossRef] [PubMed]

133. Ruhen, O.; Mirzai, B.; Clark, M.E.; Nguyen, B.; Salomon, C.; Erber, W.; Meehan, K. Comparison of Circulating Tumour DNA and Extracellular Vesicle DNA by Low-Pass Whole-Genome Sequencing Reveals Molecular Drivers of Disease in a Breast Cancer Patient. Biomedicines 2020, 9, 14. [CrossRef] [PubMed]

134. Nguyen, B.; Wong, N.C.; Semple, T.; Clark, M.; Wong, S.Q.; Leslie, C.; Mirzai, B.; Millward, M.; Meehan, K.; Lim, A.M. Lowcoverage whole-genome sequencing of extracellular vesicle-associated DNA in patients with metastatic cancer. Sci. Rep. 2021, 11, 4016. [CrossRef] [PubMed] 
135. Degli Esposti, C.; Iadarola, B.; Maestri, S.; Beltrami, C.; Lavezzari, D.; Morini, M.; De Marco, P.; Erminio, G.; Garaventa, A.; Zara, F.; et al. Exosomes from Plasma of Neuroblastoma Patients Contain Doublestranded DNA Reflecting the Mutational Status of Parental Tumor Cells. Int. J. Mol. Sci. 2021, 22, 3667. [CrossRef]

136. Castillo, J.; Bernard, V.; San Lucas, F.A.; Allenson, K.; Capello, M.; Kim, D.U.; Gascoyne, P.; Mulu, F.C.; Stephens, B.M.; Huang, J.; et al. Surfaceome profiling enables isolation of cancer-specific exosomal cargo in liquid biopsies from pancreatic cancer patients. Ann. Oncol. 2018, 29, 223-229. [CrossRef]

137. Kontopoulou, E.; Strachan, S.; Reinhardt, K.; Kunz, F.; Walter, C.; Walkenfort, B.; Jastrow, H.; Hasenberg, M.; Giebel, B.; von Neuhoff, N.; et al. Evaluation of dsDNA from extracellular vesicles (EVs) in pediatric AML diagnostics. Ann. Hematol. 2020, 99, 459-475. [CrossRef]

138. Daugaard, I.; Kjeldsen, T.E.; Hager, H.; Hansen, L.L.; Wojdacz, T.K. The influence of DNA degradation in formalin-fixed, paraffin-embedded (FFPE) tissue on locus-specific methylation assessment by MS-HRM. Exp. Mol. Pathol. 2015, 99, 632-640. [CrossRef]

139. Guyard, A.; Boyez, A.; Pujals, A.; Robe, C.; Tran Van Nhieu, J.; Allory, Y.; Moroch, J.; Georges, O.; Fournet, J.C.; Zafrani, E.S.; et al. DNA degrades during storage in formalin-fixed and paraffin-embedded tissue blocks. Virchows Arch. 2017, 471, 491-500. [CrossRef]

140. Kalluri, R.; LeBleu, V.S. The biology, function, and biomedical applications of exosomes. Science 2020, 367, eaau6977. [CrossRef]

141. Nabhan, J.F.; Hu, R.; Oh, R.S.; Cohen, S.N.; Lu, Q. Formation and release of arrestin domain-containing protein 1-mediated microvesicles (ARMMs) at plasma membrane by recruitment of TSG101 protein. Proc. Natl. Acad. Sci. USA 2012, 109, $4146-4151$. [CrossRef]

142. Wang, Q.; Yu, J.; Kadungure, T.; Beyene, J.; Zhang, H.; Lu, Q. ARMMs as a versatile platform for intracellular delivery of macromolecules. Nat. Commun. 2018, 9, 960. [CrossRef]

143. Liang, Y.; Lehrich, B.M.; Zheng, S.; Lu, M. Emerging methods in biomarker identification for extracellular vesicle-based liquid biopsy. J. Extracell. Vesicles 2021, 10, e12090. [CrossRef]

144. Crescitelli, R.; Lasser, C.; Szabo, T.G.; Kittel, A.; Eldh, M.; Dianzani, I.; Buzas, E.I.; Lotvall, J. Distinct RNA profiles in subpopulations of extracellular vesicles: Apoptotic bodies, microvesicles and exosomes. J. Extracell. Vesicles 2013, 2, 20677. [CrossRef]

145. Willms, E.; Cabanas, C.; Mager, I.; Wood, M.J.A.; Vader, P. Extracellular Vesicle Heterogeneity: Subpopulations, Isolation Techniques, and Diverse Functions in Cancer Progression. Front. Immunol. 2018, 9, 738. [CrossRef] [PubMed]

146. Oksvold, M.P.; Kullmann, A.; Forfang, L.; Kierulf, B.; Li, M.; Brech, A.; Vlassov, A.V.; Smeland, E.B.; Neurauter, A.; Pedersen, K.W. Expression of B-cell surface antigens in subpopulations of exosomes released from B-cell lymphoma cells. Clin. Ther. 2014, 36, 847-862.e1. [CrossRef] [PubMed]

147. Zhang, H.; Freitas, D.; Kim, H.S.; Fabijanic, K.; Li, Z.; Chen, H.; Mark, M.T.; Molina, H.; Martin, A.B.; Bojmar, L.; et al. Identification of distinct nanoparticles and subsets of extracellular vesicles by asymmetric flow field-flow fractionation. Nat. Cell Biol. 2018, 20, 332-343. [CrossRef] [PubMed]

148. Palmisano, G.; Jensen, S.S.; Le Bihan, M.C.; Laine, J.; McGuire, J.N.; Pociot, F.; Larsen, M.R. Characterization of membrane-shed microvesicles from cytokine-stimulated beta-cells using proteomics strategies. Mol. Cell. Proteom. 2012, 11, 230-243. [CrossRef] [PubMed]

149. Lin, J.J.; Shaw, A.T. Resisting Resistance: Targeted Therapies in Lung Cancer. Trends Cancer 2016, 2, 350-364. [CrossRef]

150. FDA Approves First KRAS Inhibitor: Sotorasib. Cancer Discov. 2021. [CrossRef]

151. Chan, T.A.; Yarchoan, M.; Jaffee, E.; Swanton, C.; Quezada, S.A.; Stenzinger, A.; Peters, S. Development of tumor mutation burden as an immunotherapy biomarker: Utility for the oncology clinic. Ann. Oncol. 2019, 30, 44-56. [CrossRef]

152. Guan, Y.F.; Li, G.R.; Wang, R.J.; Yi, Y.T.; Yang, L.; Jiang, D.; Zhang, X.P.; Peng, Y. Application of next-generation sequencing in clinical oncology to advance personalized treatment of cancer. Chin. J. Cancer 2012, 31, 463-470. [CrossRef]

153. Serrati, S.; De Summa, S.; Pilato, B.; Petriella, D.; Lacalamita, R.; Tommasi, S.; Pinto, R. Next-generation sequencing: Advances and applications in cancer diagnosis. Onco-Targets Ther. 2016, 9, 7355-7365. [CrossRef]

154. Al-Kateb, H.; Nguyen, T.T.; Steger-May, K.; Pfeifer, J.D. Identification of major factors associated with failed clinical molecular oncology testing performed by next generation sequencing (NGS). Mol. Oncol. 2015, 9, 1737-1743. [CrossRef]

155. Hagemann, I.S.; Devarakonda, S.; Lockwood, C.M.; Spencer, D.H.; Guebert, K.; Bredemeyer, A.J.; Al-Kateb, H.; Nguyen, T.T.; Duncavage, E.J.; Cottrell, C.E.; et al. Clinical next-generation sequencing in patients with non-small cell lung cancer. Cancer 2015, 121, 631-639. [CrossRef]

156. Zhang, J.; Spath, S.S.; Marjani, S.L.; Zhang, W.; Pan, X. Characterization of cancer genomic heterogeneity by next-generation sequencing advances precision medicine in cancer treatment. Precis. Clin. Med. 2018, 1, 29-48. [CrossRef]

157. Wong, S.Q.; Li, J.; Tan, A.Y.; Vedururu, R.; Pang, J.M.; Do, H.; Ellul, J.; Doig, K.; Bell, A.; MacArthur, G.A.; et al. Sequence artefacts in a prospective series of formalin-fixed tumours tested for mutations in hotspot regions by massively parallel sequencing. $B M C$ Med. Genom. 2014, 7, 23. [CrossRef] [PubMed]

158. Zill, O.A.; Greene, C.; Sebisanovic, D.; Siew, L.M.; Leng, J.; Vu, M.; Hendifar, A.E.; Wang, Z.; Atreya, C.E.; Kelley, R.K.; et al. Cell-Free DNA Next-Generation Sequencing in Pancreatobiliary Carcinomas. Cancer Discov. 2015, 5, 1040-1048. [CrossRef] [PubMed] 
159. Li, B.T.; Janku, F.; Jung, B.; Hou, C.; Madwani, K.; Alden, R.; Razavi, P.; Reis-Filho, J.S.; Shen, R.; Isbell, J.M.; et al. Ultra-deep next-generation sequencing of plasma cell-free DNA in patients with advanced lung cancers: Results from the Actionable Genome Consortium. Ann. Oncol. 2019, 30, 597-603. [CrossRef]

160. Singh, A.P.; Cheng, H.; Guo, X.; Levy, B.; Halmos, B. Circulating Tumor DNA in Non-Small-Cell Lung Cancer: A Primer for the Clinician. JCO Precis. Oncol. 2017, 1, 1-13. [CrossRef]

161. Kustanovich, A.; Schwartz, R.; Peretz, T.; Grinshpun, A. Life and death of circulating cell-free DNA. Cancer Biol. Ther. 2019, 20, 1057-1067. [CrossRef] [PubMed]

162. Zareba, L.; Szymanski, J.; Homoncik, Z.; Czystowska-Kuzmicz, M. EVs from BALF-Mediators of Inflammation and Potential Biomarkers in Lung Diseases. Int. J. Mol. Sci 2021, 22, 3651. [CrossRef] [PubMed] 